\title{
A new type of plankton food web functioning in coastal waters revealed by coupling Monte Carlo Markov chain linear inverse method and ecological network analysis
}

\author{
Meddeb Marouan 1, 2, * , Niquil Nathalie ${ }^{3}$, Grami Boutheïna ${ }^{1,4}$, Mejri Kaouther ${ }^{1,2}$, Haraldsson Matilda ${ }^{3}$, \\ Chaalali Aurelie ${ }^{3,5,6}$, Pringault Olivier ${ }^{7,8}$, Hlaili Asma Sakka 1,2
}

1 Université de Carthage, Faculté des Sciences de Bizerte, Laboratoire de phytoplanctonologie 7021

Zarzouna, Bizerte, Tunisia

2 Université de Tunis El Manar, Faculté des Sciences de Tunis, LR18ES41 Sciences de

I'Environnement, Biologie et Physiologie des Organismes Aquatiques, Tunis, Tunisia

${ }^{3}$ CNRS, Normandie Université, UNICAEN, UMR BOREA (MNHN, CNRS-7208, Sorbonne Universités,

Université Caen Normandie, IRD-207, Université des Antilles), CS 14032, Caen, France

4 Université de Monastir, Institut Supérieur de Biotechnologie de Monastir, LR-14ES06 Bioressources:

Biologie Intégrative \& Valorisation «BIOLIVAL», Avenue Taher Hadad, BP 74, 5000 Monastir, Tunisia

5 IFREMER, Ecology and Models Applied to Fishery Resources, Nantes, France

${ }^{6}$ ESE, Ecology and Ecosystem Health, Agro Campus Ouest, INRA, 35042 Rennes, France

7 Institut de Recherche pour le Développement (IRD), MARBEC Marine Biodiversity, Exploitation \&

Conservation, BP 4341004 Tunis, Tunisia

8 UMR IRD ( $\left.n^{\circ} 248\right)$, Ifremer, Univ. Montpellier, CNRS ( $\left.n^{\circ} 9190\right)$, France

*Corresponding author : Marouan Meddeb, email address : marouan.meddeb@yahoo.fr

\begin{abstract}
:
Plankton food webs (PFW) typology is based on different categories of functioning, according to the dominant processes and the role played by heterotrophic bacteria, small vs large phytoplankton, and small vs large zooplankton. Investigating the structure and the function of planktonic food webs in two SW Mediterranean waters (inshore and marine sites) at four seasons, using inverse (LIM-MCMC) and ecological network (ENA) analyses, we identified a new type of food web, called the "bacterial multivorous food web". This food web adds to the conventional trophic continuum as previously reported. The "bacterial multivorous food web" present in winter showed the lowest primary production among seasons, but highest bacterial production. Several food web ratios characterized this new typology e.g. picophytoplankton net primary production to total primary production varied from 0.20 to 0.28 ; bacterial to primary production ratio is higher than values reported in global scale $(\cong 1)$; bacterial net production to the potential protozoan prey net production was high $(>0.2)$. In this special food web, carbon was mostly recycled, with a moderate fraction channeled to deep waters, which lead to a higher retention of carbon inside the ecosystem. This winter PFW also seemed to be the most organized, specialized, stable and mature, as related to common interpretations of ENA. The spring was characterized by herbivorous food web, with highest activity coinciding with low stability. Although less usual, the herbivorous pathway was also observed during summer, in inshore waters. The autumn food webs, which functioned as multivorous
\end{abstract}


or microbial food webs, appeared to be stable and mature. Finally, our study demonstrates the usefulness of food web models derived ratios combined with ecological network analysis indices to conduct evaluation of the structure and functioning of ecosystems and potentially to support management decisions in marine environment.

\section{Highlights}

- The seasonal change in food webs structure resulted in a shift in the properties and functioning of the system. New planktonic food web was identified using inverse method (LIM-MCMC) and ecological network (ENA). The "Bacterial multivorous food web" dominated winter and showed the lowest primary production among seasons, but highest bacterial production. ENA analysis showed a high carbon retention and a most organized and specialized statute of the bacterial multivorous food web.

Keywords: Food web modeling, Network analysis, Trophic structure, Coastal waters, Seasonal variations, Ecology, Bacterial multivorous food web 


\section{Introduction}

Marine biological productivity depends on the magnitude of phytoplankton production and its trophic transfer through food webs. The structure and the functioning of the food web can in turn influence the energy flow and the carbon cycling in marine ecosystems (Vargas et al., 2007). In addition, the structure of plankton food webs can vary greatly over seasons, since seasonal change in environmental conditions (mainly the availability of nutrients, light and hydrological conditions) can affect the abundance, the size structure and the composition of plankton communities as well as the tropho-dynamics within the plankton system (Sankar and Padmavathi, 2012; Vajravelu et al., 2017; Rasconi et al., 2017). For temperate regions, there exist a conventional scheme describing the food web dynamics over seasons (Legendre and Rassoulzadegan, 1995). The increasing light during spring and the stratification of the water column, which has already been enriched by nutrients during winter mixing, lead to phytoplankton blooms dominated by micro-sized algae (i.e. diatoms $>10 \mu \mathrm{m}$. This high production is consumed by herbivorous zooplankton (i.e. copepods) and efficiently channeled to higher trophic levels, or exported to deeper layers (Ryther, 1969; Turner, 2001). In summer, the persistent water column stability causes a depletion of nutrients in the surface waters, causing a decrease in production and a shift in the primary producers, dominated by pico- and nano-sized algae and bacteria. This production is consumed by microbivorous zooplankton (i.e. heterotrophic nanoflagellates and microzooplankton) and transferred to higher consumers through the microbial food web (Calbet and Landry, 2004). In autumn, storms can erode water column stability and amend nutrients in the surface water, resulting in a small autumnal phytoplankton bloom that rapidly decline as light decreases. In this situation, both the microbial pathways and grazing on larger phytoplankton are important, resulting in the multivorous food web (Legendre and Rassoulzadegan, 1995). In winter, under mixed water conditions, the food web can typically function as a microbial pathway (Marquis et al., 2007). Recently, Sakka Hlaili et al. (2014), have proposed two new food webs, based on modeling data of planktonic food webs in oceanic and coastal regions, which adds to the continuum of food web dynamics by Legendre and Rassoulzadegan (1995). They identified the "phyto-microbial food web", where microzooplankton feeding on phytoplankton is more important than grazing on bacteria, and the "poly-microbial food web", where microzooplankton consume more or less equally the various types of food.

In the Mediterranean Sea, open waters (e.g. Aegean Sea, Levantine basin and Ligurian Sea) are basically oligotrophic supporting low phytoplankton biomass $\left(<0.2 \mu \mathrm{g} \mathrm{Chl} a 1^{-1}\right)$ and 
primary production (59-150 $\mathrm{g} \mathrm{C} \mathrm{m}^{-2} \mathrm{y}^{-1}$, Siokou-Frangou et al., 2010). A large part of fixed carbon is channeled to higher tropic levels through microbial organisms, as small-size autotrophs and heterotrophs are dominant in most seasons (Siokou-Frangou et al., 2002; Zervoudaki et al., 2011; Giannakourou et al., 2014). On the contrary, the coastal waters are more productive environments (200-400 $\mathrm{g} \mathrm{C} \mathrm{m}^{-2} \mathrm{y}^{-1}$, Nixon, 1995), mainly due to the high nutrient availability that promotes intense spring diatom-blooms. Here, phytoplankton production is efficiently transferred to higher trophic levels through the herbivorous food web (Caroppo et al., 2000; Auger et al., 2011; Alekseenko et al., 2014).

Establishing the food webs structure in the marine planktonic community is one of the most important steps to predict the ecosystem functioning and to understand the cycling of materials and flows of energy. The structure of the food web is intimately linked to the size structure of the primary producers, which itself depends on the hydrological conditions that control nutrient availability and stratification (Thingstad and Rassoulzadegan, 1999; Irigoien et al., 2005; Marquis et al., 2007). In the present study, an inverse analysis (Linear Inverse Analyses, LIM) approach was used to examine food web interactions in two coastal regions in Southern Mediterranean, the Bay and the Channel of Bizerte in Northern Tunisia. Inverse method, evolved from the physical sciences (Vézina and Platt, 1988), has been used to solve the problem of quantification of missing carbon flows through the plankton food web. Effectively, marine food webs are complex systems with various interactions that are difficult to estimate directly or entirely in field. The LIM approach has been applied to describe food web interactions in various marine ecosystems, as the Gulf of Riga, the Bay of Biscay, the Lagoon of Takapoto, the Northeast Subarctic Pacific and the Baltic Sea (Donali et al., 1999; Vézina and Savenkoff, 1999; Niquil et al., 1998, 2001; Marquis et al., 2007). In the Mediterranean Sea, different modeling analyses have been used to examine the functioning and the structure of food webs and related driving factors. Ecophath with Ecosim (EWE) approach (Coll and Libralato, 2012) is the most used approach in Mediterranean regions, including the Gulf of Gabès (South of Tunisia, Hattab et al., 2013), the Western, Central and Eastern Mediterranean Sea (Tecchio et al., 2015, Heymans et al., 2014), and for the entire Mediterranean Sea (Piroddi et al., 2015, 2017). The three dimensional modeling approach has also been used in the Northwestern Mediterranean basin (Herrmann et al., 2013; Auger et al., 2014) and the Gulf of Lion (Auger et al., 2011). The LIM have been applied in some Mediterranean waters, such as, the Lagoon of Bizerte (Grami et al., 2008) and coastal waters of the Mediterranean Sea (Olsen et al., 2001). This method was modified into the Monte Carlo Markov Chain Linear Inverse method (LIM-MCMC; Van den Meersche et al., 2009). 
The LIM-MCMC, allows us to estimate the uncertainty around flows, to perform statistical tests, to compare many marine systems over different seasons and has been applied in many marine ecosystems (De Laender et al., 2010; Grami et al., 2011; Saint-Béat et al., 2014; Chaalali et al., 2015). Nevertheless, the food web structure and the trophic-interaction functioning have so far been poorly described for the southern Mediterranean regions, despite the high plankton diversity and the pronounced productivity observed there (Sakka Hlaili et al., 2008, Bel Hassen et al., 2008; Hafferssas and Seridji, 2010). Up to date, the food web of Bizerte Lagoon has been modeled during summer (Grami et al., 2008), showing an efficient transfer of primary production through the herbivory of microzooplankton. Also, the food webs of the Bay, Channel and Lagoon of Bizerte has been modelled during spring (Meddeb et al., 2018). However, these studies were based on data collected during one season only, and there exist little knowledge about the seasonal variability in food web structures and dynamics in this region and how they fit with the typology of plankton functioning. Using the LIMMCMC method, our study aims to describe the seasonal dynamics of plankton food webs in the Bay and the Channel of Bizerte in relation to hydrological conditions. We used the ENA to characterize some functional properties of the system and to compare seasonal differences in stress levels and stability of the food webs, two attributes of primary importance in the objective of implementing an ecosystem based management of this environment.

\section{Materials and Methods}

\subsection{Study areas}

The Bay of Bizerte is an important fishing region located in the south-western Mediterranean basin (Fig. 1), with depth varying from 16 to $20 \mathrm{~m}$. The Bay is an open embayment facing the Western Mediterranean basin, which is largely influenced by surface Modified Atlantic Water (MAW) (Millot, 1987, 1999). Throughout the year, this water crosses the Straits of Gibraltar and runs along the North African coasts and reaches the northern Tunisian coasts before branching into two veins, one towards the eastern basin and one towards the Tyrrhenian Sea. The MAW caused a mixed layer of 40-50 m with salinity increasing from Gibraltar (36 psu) to the Algera-Provençal basin (38psu). Consequently, the hydrological structure of the water column in the Bay seems to vary little among seasons. The Bay is located in the semi-humid bioclimatic zone, with significant periods of rainfall (especially in winter) causing an important inputs of terrestrial nutrients. Nutrients are commonly abundant in the surface layers throughout the year $(0.1-0.7 \mathrm{P} \mu \mathrm{M} ; 1-3.5 \mathrm{~N} \mu \mathrm{M}$; 0.5-2.25 Si $\mu \mathrm{M}$ ) (Sahraoui et al., 2009). Seasonal dynamics has previously been shown for phytoplankton, with high chlorophyll biomass $\left(2-4 \mu \mathrm{g}^{-1}\right)$ during spring and summer, and 
lower values in the other seasons $\left(<1.5 \mu \mathrm{g}^{-1}\right)$. This coincided with the predominance of diatoms $\left(10^{5}\right.$ cells $\left.1^{-1}\right)$ in spring and summer, and of nanoflagellates during the rest of the year (Sahraoui et al., 2009, Meddeb et al., 2018). Diatoms are also present in autumn and winter and may contribute up to $20-35 \%$ to the phytoplankton assemblage (Sahraoui et al., 2009). The Channel of Bizerte, $7 \mathrm{~km}$ long, $300 \mathrm{~m}$ wide and $12 \mathrm{~m}$ deep, connects the Lagoon of Bizerte to the Bay, and is therefore influenced by marine inflow from the Bay, particularly during summers.

The Lagoon is the most important Tunisian site of fisheries and bivalve culture. The tidal regime in the region is dominated by a semi-diurnal cycle with a low amplitude $(<15$ $\mathrm{cm}$ ), but the current velocities can reach $1 \mathrm{~m} \mathrm{~s}^{-1}$ in the middle of the Channel (Harzallah, 2003; Béjaoui et al., 2008). The Lagoon receives a large amount of freshwater from several rivers and from the big lake of Ichkeul due to strong rains during winter and spring, which also influences the Channel during these seasons (Ben Ismail et al., 2012; Zaaboub et al., 2015). In addition, by receiving high nutrient inputs and effluents from land from several anthropogenic activities (1-11.5 P $\mu \mathrm{M} ; 3.5-55 \mathrm{~N} \mu \mathrm{M}$; 2-11Si $\mu \mathrm{M}$, Bouchouicha et al., 2012), the Channel is considered as a more eutrophied system than the Bay. Pronounced diatom blooms $\left(10^{6}\right.$ cells $\left.1^{-1}\right)$ were previously observed in the Channel during summer. Diatoms are also present in spring together with nanoflagellates. These latter predominated during other seasons (Bouchouicha et al., 2012).

\subsection{Sampling and hydrological structure of the water column}

Data for the study were obtained from several surveys conducted during four seasons (spring, summer, and autumn 2012, and winter 2013) at a marine station located in the Bay (station B, 37 $16^{\prime} 54^{\prime \prime} \mathrm{N}, 9^{\circ} 53^{\prime} 42^{\prime \prime} \mathrm{E}$ ) and an inshore station in the Channel (station $\mathrm{C}$, $37^{\circ} 15^{\prime} 04^{\prime \prime} \mathrm{N}, 9^{\circ} 52^{\prime} 34^{\prime \prime}$ E) (Fig.1). During each season, the sampling was carried out at four depths of each station $(0.5,2.5,5 / 6$ and 8/16 m) using an acid-washed 2.5-L plastic water sampler (Hydro-Bios). Sampled water was filtered through a $200 \mu \mathrm{m}$ mesh screen to remove meso- and macrozooplankton (except water used for DOC determination) and stored in polyethylene containers until analyses. Metazooplankton, for two size classes $(200-700 \mu \mathrm{m}$ and $>700 \mu \mathrm{m}$ ), were sampled using two vertical net tows with $200 \mu \mathrm{m}$ and $700 \mu \mathrm{m}$ screen mesh. Vertical profiles of salinity and temperature were measured in situ with a microprocessor conductivity meter (LF 196) (Fig. 2).

Nutrient concentrations $\left[\mathrm{NO}_{3}{ }^{-}, \mathrm{NO}_{2}{ }^{-}, \mathrm{NH}_{4}{ }^{+}, \mathrm{PO}_{4}{ }^{3-}\right.$ and $\left.\left.\mathrm{Si}(\mathrm{OH})_{4}\right)\right]$ were measured at the four depth of each station $(0.5,2.5,5 / 6$ and $8 / 16 \mathrm{~m})$, following the spectrophotometric method (Parsons et al., 1984). 


\subsection{Linear Inverse Method-Monte Carlo Markov Chain analysis (LIM-MCMC)}

To have a complete quantification of the processes in the food web, we used the inverse analysis method to estimate the unknown flows from the known ones. The LIM-MCMC method (Van Den Meersche et al., 2009), derived from the inverse analysis method of Vézina and Platt (1988), was adopted to reconstruct trophic carbon flows through the eight planktonic food webs. This approach is based on four steps: (i) building an a priori model including all possible flows between the considered compartments or between the compartments and the outside; (ii) setting mass-balance between flows, for each compartment, as equalities; (iii) setting two groups of inequalities, the first ones based on in situ calculated flows, and the second ones consists on a number of biological constraints taken from the literature, to reduce the range of possible values for each flow; and (iv) calculating a large sample of possible solutions for unknown flows.

\subsubsection{A priori model}

The a priori model describes all possible carbon flows among the trophic compartments. For all seasons, the model (Fig. 3) includes nine compartments: heterotrophic bacteria (bac), picophytoplankton (pic, <2 $\mu \mathrm{m}$ ), nanophytoplankton (nan, 2-10 $\mu \mathrm{m}$ ), microphytoplankton (mic, 10-200 $\mu \mathrm{m}$ ), protozooplankton (pro = heterotrophic nanoflagellates, dinoflagellates and ciliates, <200 $\mu \mathrm{m}$ ), metazooplankton 200-700 $\mu \mathrm{m}$ (met1), metazooplankton $>700 \mu \mathrm{m}$ (met2), dissolved organic carbon (doc) and detritus (det). Fortythree flows were considered in the a priori model of each season (Fig. 3, Table 3).

The gross primary production (gpp) of the three phytoplankton size fractions (pic, nan, and mic) is the only source of carbon input to the network. Carbon loss is driven by respiration of all living compartments and sinking of all compartments except protozooplankton, picophytoplankton and bacteria. We assumed that the very small size of pic and bac did not allow them to generate sinking flux. Detritus dissolution, phytoplankton exudation and zooplankton excretion (i.e. by pro, met1 and met2) contributed to the doc pool. Doc was only used by bacteria, since other potential consumers of doc (such as choanoflagellates) were absent in our samples. All living compartments, except bac and pic, contributed to the detritus pool through mortality, production of feces by metazooplankton (i.e. met1 and met2) and zooplankton sloppy feeding. Protozooplankton grazed on bac, pic and nan, but also on mic, since they have been reported as potential grazers on large preys in several coastal areas, including our study sites (Meddeb et al., 2018). Metazooplankton, known as inefficient grazers on particles $<5 \mu \mathrm{m}$ (Fortier et al., 1994), consumed nano- and microphytoplankton, but not picophytoplankton. Protozooplankton and detritus represented 
another food source for the two size classes of metazooplankton (met1 and met2), while large metazoans (met2) consumed smaller ones (met1).

\subsubsection{Equalities and inequalities}

Establishing the set of linear equalities is an essential step to obtain the mass balances of the network. If the mass of the compartment is stable during the period considered, the sum of the flows entering into this compartment should equal to the sum of the flows leaving it. The mass balance equations for all compartments are given in Table 1.

Imposing linear inequalities for each unknown flow helps to reduce the range of possible solutions. Two ranges of inequalities were adopted, as previously considered in Meddeb et al. (2018). Firstly, a bound of an upper and lower values for each flow were considered by the calculation of a confidence interval around the field data, i.e. using the minimum and maximum of the average value of each flows estimated in situ (Table 2). More details are given in Meddeb et al. (2018).

A second group of constraints was adopted to constrain the unknown flows. For all seasons, the inequalities used for the Channel and the Bay models were described in several previous works (Pace et al., 1984; Vézina and Platt, 1988; Vézina and Pace, 1994; Vézina and Savenkoff, 1999; Steinberg et al., 2000; Vézina et al., 2000; Vézina and Pahlow, 2003). They constrain the respiration of bacteria, phytoplankton, protozooplankton and metazooplankton; the doc production by phytoplankton, bacteria and zooplankton; the growth efficiency of bacteria and zooplankton; the assimilation efficiency of zooplankton; the detritus production by zooplankton and the dissolution of detritus (Table 4).

\subsubsection{Solutions}

The last step of the inverse analysis was the calculation of unknown flows. The estimations of each unknown flow were obtained by the LIM-MCMC method, based on the mirror technique defined by Van Den Meersche et al. (2009). A jump value of $10 \mathrm{mgC} \mathrm{m} \mathrm{m}^{-2}$ and 300000 iterations were adopted to run the models in order to optimize the coverage of all

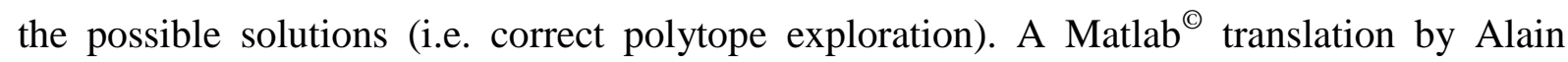
Vézina and Lauriane Campo of the R-CRAN project package LIM-Solve was used (Van den Meersche et al., 2009). More details on the method are available in Van Den Meersche et al. (2009) and Niquil et al. (2012).

\subsection{Data}

Data used in the eight models were collected during seasonal samplings atthe Bay and the Channel. These data permitted to determine 14 carbon flows for each model. In each sites, sampled water has served for the determination of doc and particulate organic carbon (POC) 
concentrations as well as the plankton abundance and diversity. See Meddeb et al. (2018) for more details on the preservation of samples and analyses. Briefly, Samples for doc measurement were filtered on sterilized $0.2 \mu \mathrm{m}$ polycarbonate filters before being analyzed using a Shimadzu TOC-5000 carbon analyser (Knap et al., 1993). The carbon concentration of doc was obtained considering that $1 \mu \mathrm{M}$ of doc is equal to $12 \mathrm{mg} \mathrm{C} \mathrm{m}^{-3}$ (Grami et al., 2008; Meddeb et al., 2018). POC was analysed on a CHN elemental analyser (Perkin-Elmer 2400) after filtration of samples through pre-combusted (at $450^{\circ} \mathrm{C}$, during $2 \mathrm{~h}$ ) $\mathrm{GF} / \mathrm{F}$ Whatman filters (21 mm) (Knap et al., 1996).

Heterotrophic bacteria and picophytoplankton (pic= prokaryotes and eukaryotes) were enumerated under a CETI Topic-T epifluorescence microscope on samples filtered through $0.22 \mu \mathrm{m}$ black polycarbonate filters (Nuclepore) laid over $0.45 \mu \mathrm{m}$ nitrocellulose backing filters (Millipore) (Parsons et al., 1984; Mac Isaac and Stockner, 1993). The mean cell volume of bac and pic was converted into cell carbon using specific conversion factors, $0.35 \mathrm{pg} \mathrm{C} \mathrm{mm}^{-}$ ${ }^{3}$ for bacteria (Bjørnsen, 1986), $0.22 \mathrm{pg} \mathrm{C} \mathrm{mm}^{-3}$ for prokaryotic pic (Søndergaard et al., 1991) and $0.22 \mathrm{pg} \mathrm{C}$ cell $^{-1}$ for eukaryotic pic (Mullin et al.,1966). Phytoplankton (nan and mic) and protozooplankton were counted and identified under an inverted microscope (Lund et al., 1958) on $100 \mathrm{ml}$ settled samples fixed with $3 \%$ acid Lugol solution and 5\% alkaline Lugol solution, respectively. The mean cell volume of each taxon of phytoplankton and protozooplankton was determined by applying standard geometric shape, as proposed by Hillebrand et al. (1999). Then, the mean cell volumes were converted to cell carbon using specific formula or factors (see Table 1, Meddeb et al., 2018).

Metazooplankton samples were preserved in borate-buffered formalin $(5 \%$ final concentration) for identification and counts of organisms under a dissecting stereomicroscope (Leica). For each metazoan organism, the length and the width were converted into carbon content using conversion factors corresponding to each taxonomic group, as detailed in Meddeb et al. (2018). For each plankton group (bac, pic, nan, mic, pro, met1 and met2), the carbon biomass was estimated by multiplying their carbon content by their corresponding abundances. The detrital organic carbon (det) was estimated as total POC, determined from water column, minus the total carbon biomass of all plankton communities. Finally, the areal carbon stocks $\left(\mathrm{mg} \mathrm{C} \mathrm{m}^{-2}\right.$ ) for each living and non-living compartments were calculated by vertically integrating the carbon biomass calculated for each sampling depth. More details of calculations are given in Meddeb et al. (2018). 
The gross production rate of size-fractionated phytoplankton (pic, nan and mic) and bacteria as well as consumption rate of these living components by protozooplankton were seasonally assessed at each sampling depth of each site by in situ dilution experiments (Landry and Hassett, 1982). This method is relatively simple to set up, it minimizes the manipulation and disruption of the micrograzer population and is an appropriate technique for determining total microzooplankton grazing activity (Sakka Hlaili et al., 2008; Grattepanche et al., 2011). Details for experimental procedure and calculation are provided in Meddeb et al. (2018) and Meddeb et al. (submitted).

Dilution experiments could be described as mixing free-particle sea water (filtred on 0.2 $\mu \mathrm{m}$ ) with pre-filtred water on $200 \mu \mathrm{m}$ mesh net (to remove meso- and macrozooplankton grazing effect) to give four dilution factors $(100 \%, 75 \%, 50 \%$ and $25 \%)$. Each dilution mixture was then distributed into three clean $2 \mathrm{~L}$ polycarbonate bottles, incubated in situ at the sampling depths fortnight. The estimated rates $\mathrm{k}$ and $\mathrm{g}$ were used to calculate gross production rates for phytoplankton and bacteria $\left(\mathrm{P}, \mathrm{mg} \mathrm{C} \mathrm{m}^{-3} \mathrm{~d}^{-1}\right)$ and their consumption rates $(\mathrm{G}, \mathrm{mg} \mathrm{C}$ $\mathrm{m}^{-3} \mathrm{~d}^{-1}$ ) as suggested by Moigis (2000) and in more recent works (Sakka Hlaili et al., 2008, Grattepanche et al., 2011):

$$
\begin{aligned}
& P=\mathrm{kx} \mathrm{C}_{0}\left[\mathrm{e}^{(\mathrm{k}-\mathrm{g}) \mathrm{t}}-1\right] /(\mathrm{k}-\mathrm{g}) \times \mathrm{t} \\
& \mathrm{G}=\mathrm{gxC}_{0}\left[\mathrm{e}^{(\mathrm{k}-\mathrm{g}) \mathrm{t}}-1\right] /(\mathrm{k}-\mathrm{g}) \times \mathrm{t}
\end{aligned}
$$

where $\mathrm{C}_{0}\left(\mathrm{mg} \mathrm{C} \mathrm{m}^{-3}\right)$ is the initial biomass of phytoplankton or bacteria, $\mathrm{k}$ is the growth rates of bacteria and size-fractionated phytoplankton $\left(\mathrm{d}^{-1}\right), \mathrm{g}$ is the grazing rates by protozooplankton $\left(\mathrm{d}^{-1}\right)$ and $\mathrm{t}(\mathrm{d})$ is the incubation time $(1 \mathrm{~d})$.

The areal rates $\left(\mathrm{mg} \mathrm{C} \mathrm{m}^{-2} \mathrm{~d}^{-1}\right)$ of production $(\mathrm{P})$ and consumption $(\mathrm{G})$ were determined by integrating the values obtained from the four sampling depths.

The consumption rates of phytoplankton (nan and mic) by metazooplankton (met1 and met2) were estimated by gut content experiments (Slaughter et al., 2006), which were conducted seasonally at each sites. The description of the experiment procedure and the calculation were detailed in Meddeb et al. (submitted).

Metazooplankton vertically sampled from bottom to surface in each site allowed the calculation of phytoplankton grazing by two size fractions of metazoa (200-700 $\mu \mathrm{m}$ and $>700$ $\mu \mathrm{m})$. Subsamples $(0.5 \mathrm{~L}$ or $1 \mathrm{~L})$ were filtered $(47 \mathrm{~mm} \mathrm{GF} / \mathrm{F})$, homogenized (90\% acetone) and filtered through $25 \mathrm{~mm} \mathrm{GF/F}$ filters to remove pulp. The filtrates containing extracted gut 
pigment were measured before and after acidification with $10 \%$ hydrochloric acid using the spectrophotometric method of Lorenzen (1967).

Gut pigment content (GP, mg pigment $\mathrm{m}^{-3}$ ) was calculated using the following equation:

$$
\mathrm{GP}=\left(\mathrm{GP}_{\text {sub }} \times \mathrm{v}\right) /\left(\mathrm{F} \times \mathrm{V}_{\text {net }}\right)
$$

where, $\mathrm{GP}_{\text {sub }}$ is the gut pigment concentration $\left(\mathrm{mg}\right.$ pigment $\left.\mathrm{m}^{-3}\right)$ from the subsample, $\mathrm{v}\left(\mathrm{m}^{3}\right)$ is the volume of the subsample, $\mathrm{F}$ is the fraction of subsample processed for gut pigment content, and $\mathrm{V}_{\text {net }}\left(\mathrm{m}^{3}\right)$ is the total volume of water filtered during each net tow.

Metazooplankton grazing rate $\left(\mathrm{GM}, \mathrm{mg} \mathrm{C} \mathrm{m}^{-3} \mathrm{~d}^{-1}\right)$ was calculated as:

$$
\mathrm{GM}=\mathrm{GP} \times \mathrm{WC} \times \mathrm{C}: \mathrm{Chl} a
$$

where GP (mg pigment $\mathrm{m}^{-3}$ ) is the concentration of gut pigment, $\mathrm{C}: \mathrm{Chl} a$ is the depth-averaged $\mathrm{C}: \mathrm{Chl} a$ ratio determined for $>2 \mu \mathrm{m}$ phytoplankton (i.e. nano- and microphytoplankton) at each station, and $\mathrm{WC}\left(\mathrm{d}^{-1}\right)$ is the portion of water cleared per day.

Finally, GM was multiplied by the vertical depth of the net tow at each site to estimate the areal rate of consumption of metazooplankton $\left(\mathrm{GM}_{\mathrm{C}}, \mathrm{mg} \mathrm{C} \mathrm{m}^{-2} \mathrm{~d}^{-1}\right)$.

Sediment traps were used to measure sinking rates of particles and faecal pellets, during each season and at each site, as described in Meddeb et al. (2018).

\subsection{Ecological Network Analysis}

Ecological network analysis (Ulanowicz, 1997) was used to describe and to characterize the structural properties and function of plankton food webs resulted from the LIM-MCMC analysis. The MATLAB ${ }^{\odot}$ algorithms, written by Carole Lebreton and Markus Schartau (GKSS Research Center, Geesthacht Germany), were used to calculate the indices that characterize food webs in term of activity, organization, specialization, recycling, maturity and stability (Table 5). The ENA indices used in this work as trophic functioning indicators were the total system throughput (TST), the ascendency (A), the development capacity (DC), the relative ascendency (A/DC), the average path length (APL) the Finn cycling index (FCI) and the detritivory/herbivory ratio $(\mathrm{D} / \mathrm{H})$. The definition and the formulae calculation of these indices are presented in Table 5.

\subsection{Cliff's $\delta$ test for comparing network indices between seasons}

The statistical comparison between the four seasons, concerning the set of indices calculated under Matlab (TST, DC, A, A/DC, APL, FCI and D/H) was performed with Cliff's $\delta$ test, which is usually used when having large sample sizes (here 300000 values for each flow) (Tecchio et al., 2016). For each ENA index, six pairwise comparisons were performed (comparing seasons) using the effsize package under R (version 3.4.3, www.r-project.org). 
352

353

354

355

356

357

358

359

360

361

362

363

364

365

366

367

368

369

370

371

372

373

374

375

376

377

378

379

380

381

382

383

384

Then, the following values were used to define small, medium, and large effects according to Romano (2006). No p values can be calculated based on delta.

\section{Results}

\subsection{Hydrodynamic status}

Water temperatures, which were similar among stations and over depths, showed a seasonal cycle, ranging between a minimum in winter $\left(12-13.7{ }^{\circ} \mathrm{C}\right)$ and a maximum in summer $\left(25.7-27.1^{\circ} \mathrm{C}\right)$. In the Bay, the salinity showed little variation within and between depths and seasons (36.9-37.4 psu). The water column of the Channel was vertically homogenous regarding the salinity during summer, autumn and winter (36.5-37.5 psu). In contrast, there was a haline stratification of the inshore water during spring due to low saline surface water coming from the Bizerte Lagoon. During this season, there was an exceptional decrease of salinity in the Lagoon (14-24 psu) caused by important river runoff associated with a large amount of rain during the winter 2012 (213 mm, INM, 2013). Further, high levels of nutrients were recorded in the Channel (Fig. 4). In both stations, pronounced concentrations of $\mathrm{NO}_{2}^{-}, \mathrm{NO}_{3}{ }^{+}$, and $\mathrm{NH}_{4}{ }^{+}$were detected in spring, summer and autumn (10$24 \mu \mathrm{M})$ compared to the winter $(3-4 \mu \mathrm{M})$ (Fig. $4 \mathrm{~A}) . \mathrm{PO}_{4}{ }^{3-}(0.14-0.99 \mu \mathrm{M})$ and $\mathrm{Si}(\mathrm{OH})_{4}(0.84-$ $2.86 \mu \mathrm{M}$ ) were available throughout the year in both stations (Fig. 4 B, C).

\subsection{Primary and bacterial production}

The LIM-MCMC analysis allowed the estimation of 44 carbon flows for each study site during each season (Table 3 ).

The primary production was relatively high during spring (966-727 $\mathrm{mg} \mathrm{C} \mathrm{m}^{-2} \mathrm{~d}^{-1}$ ), moderate in summer and autumn (394-571 $\left.\mathrm{mg} \mathrm{C} \mathrm{m}^{-2} \mathrm{~d}^{-1}\right)$ and low in winter (160-256 $\left.\mathrm{mg} \mathrm{C} \mathrm{m}^{-2} \mathrm{~d}^{-1}\right)$ (Fig. 5). During most seasons and in both stations, microphytoplankton (mic) contributed significantly to total production (Bay: 48-84\%; Channel: 60-82\%), except in the inshore station during autumn, when the proportion of picophytoplankton production was high $60 \%$. During the rest of the year, the picophytoplankton contribution ranged from 10 to $29 \%$. Nanophytoplankton production had low proportion during spring-summer (8-29\%) and even lower $(0.29-3.03 \%)$ in autumn-winter in all stations.

In both sites, bacterial production was low from spring to autumn (48-117 $\left.\mathrm{mg} \mathrm{C} \mathrm{m}^{-2} \mathrm{~d}^{-1}\right)$ and significantly increased in winter (135-274 $\left.\mathrm{mg} \mathrm{C} \mathrm{m}^{-2} \mathrm{~d}^{-1}\right)$. Bacterial production was very low relative to primary production (5 to 15 times less) in most cases, but in winter, it almost equaled the phytoplankton production at inshore and marine stations.

\subsection{Carbon outflows}


Respiration constituted the major carbon outflow from the eight model systems, with higher proportion during winter (66-84\% of gross primary production) compared to the other seasons (45-53\%) (Fig. 6). Carbon sinking contributed from $26-31 \%$ and $14-29 \%$ of gross primary production, respectively, in the inshore and marine stations (Fig. 6A, B). Added to these two carbon loss pathways, the remaining carbon could be available for trophic transfer via the predation on metazooplankton. This trophic transfer was high during spring, summer and autumn (21-31\% of gross primary production), but did not exceed $2 \%$ in winter at both stations (Fig. 6A, B).

\subsection{Carbon flows to grazers}

In the eight plankton food webs, the diet of protozooplankton was mainly composed of autotrophs during spring (90-97\%), summer (86-88\%) and autumn (86-93\%), but equally shared between bacteria and phytoplankton in winter (i.e. mic and pic) (Fig.7A). Microphytoplankton formed the main prey of protozoa in both stations during spring (73$77 \%$ of total diet) and summer (36-47\% of total diet). During autumn, microalgae remained the major food source in the marine station (66\% of total diet), but in the inshore food web, picophytoplankton supplied $67 \%$ of carbon demand. The proportion of nanophytoplankton to protozoan diet was low in spring and summer (3-22\%) and even lower during autumn and winter $(<2 \%)$.

In both sites, metazooplankton was mainly carnivorous, since protozooplankton and small metazoan (met1) formed their major food source in all seasons (40-62\% of total diet). Herbivory of metazooplankton was low ( $<15 \%$ of total diet), but increased slightly (20-25\% of total diet) in some cases (i.e. in spring and winter, in the inshore and marine stations). Detritus formed almost half of the food for the mesozooplankton during summer. The detritus contributed little to the metazoan diet in spring and autumn (26-45\%) and even lower in winter (15-20\%) (Fig. 7B).

\subsection{Structural and functional proprieties of food webs}

The total system throughput (TST) varied proportionally to the total input in the plankton food web system. This index, related to the total activity of the system, was high in spring (2934-3818 $\left.\mathrm{mg} \mathrm{C} \mathrm{m}^{-2} \mathrm{~d}^{-1}\right)$, moderate in summer and autumn (1733-1743 and 1710$2384 \mathrm{mg} \mathrm{C} \mathrm{m}^{-2} \mathrm{~d}^{-1}$ ) and low in winter (879-1562 $\mathrm{mg} \mathrm{C} \mathrm{m}^{-2} \mathrm{~d}^{-1}$ ) (Fig. 8). The two food webs in spring exhibited the highest development capacity (DC)(Channel: $11.106 \mathrm{mg} \mathrm{C} \mathrm{m}^{-2} \mathrm{~d}^{-1}$; Bay: $8489 \mathrm{mg} \mathrm{C} \mathrm{m}^{-2} \mathrm{~d}^{-1}$, Fig. 8, Table 6) compared to the other seasons (2634-6951 $\mathrm{mg} \mathrm{C} \mathrm{m}^{-2} \mathrm{~d}^{-1}$ ) (Fig. 8). The ascendency showed similar pattern as DC, with higher values in spring (4838$\left.6054 \mathrm{mg} \mathrm{C} \mathrm{m}^{-2} \mathrm{~d}^{-1}\right)$ in comparison to the rest of the year (1566-3963 $\mathrm{mg} \mathrm{C} \mathrm{m}^{-2} \mathrm{~d}^{-1}$, Fig. 8, 
Table 6). The A/DC ratio, which quantifies the degree of organization (information) of the system, reached higher values in winter (59.4-59.6\%, Fig. 8) and decreased from autumn (57-58\%) to spring (54.5-56\%) and summer (53.4-53.9\%) (Fig. 8). The highest values of APL, that quantifies the capacity of retention of the system, were detected in winter (4.485.09) in both sites, while the lowest ones were recorded during spring in both sites (2.953.03) and during summer in the Channel (3.20). Similarly, the Finn cycling index was highest in winter (41-46\%). During autumn (for both sites) and summer (for the channel), this index reached higher values (16-17\%) than in spring (for both sites) and summer (for the Bay) (1314\%) (Fig. 8, Table 6). Finally, the detritivory/herbivory ratio (D/H) showed significant increases during summer (0.59-0.66, Fig. 8, Table 6) in both sites and moderate (0.22-0.48, Fig. 8, Table 6) to lower values $(0.05-0.12$, Fig. 8, Table 6) were observed respectively during the spring, autumn and winter in all study sites.

\section{Discussion}

\subsection{Hydrodynamics and nutritional status over seasons}

The Bay of Bizerte is characterized by marine water mainly originated from the surface Modified Atlantic Water (MAW) (Millot, 1987, 1999), which flow into the Bay throughout the year. Even in winter, the freshwater discharges from the rivers surrounding the Lagoon of Bizerte only partly reaches the Bay. These conditions can lead to little variation of hydrological structure throughout the year. Consequently, nutrients were available throughout the year inside the Bay. In contrast, the Channel was influenced both by the marine water from the Bay (mostly in summer) and by lagoonal water (mostly in winter). Hence, the spring situation within the Channel was characterized by a strong halocline resulting from low saline surface water coming from the Lagoon of Bizerte, which was caused by an important river runoff during late winter (Fig.2A). In summer, the direction of the current was reversed, with an inflow of marine water from the Bay resulting in well mixed water (Fig. 2A). In autumn vertical mixing became more important, resulting in a well-mixed water column rich in nutrients (Fig. 3). This hydrological situation was maintained in winter with lower nutrient levels (particularly for nitrogenous nutrients).

\subsection{Description of the new type of planktonic food web}

To identify the dominant trophic pathway in marine environment, Sakka Hlaili et al. (2014) have proposed a specific ratio: the ratio of picophytoplankton net production to total phytoplankton net production ( $\mathrm{R} 7$ ratio). This ratio was proposed by the authors to discriminate between herbivorous ( $\mathrm{R} 7 \leq 0.1)$, multivorous (R7: $0.1-0.6)$, and microbial food webs $(\mathrm{R} 7 \geq 0.6)$. Based on this ratio, the spring food webs encountered in the Channel $(\mathrm{R} 7=$ 
0.1 ) acted almost as a multivorous structure with a tendency towards herbivorous one, and the Bay $(\mathrm{R} 7=0.07)$ functioned as herbivorous pathways. During the summer food web functioned as herbivorous pathway in the Channel $(\mathrm{R} 7=0.1)$, and as multivorous in the Bay $(\mathrm{R} 7=0.27)$. The situation in autumn was different between the sites (Fig. 9A, B). In the Bay, the food web did not change much in structure from that in summer and continued to function as a multivorous pathway $(\mathrm{R} 7=0.21)$, while, it functioned approximately as a microbial pathway in the Channel $(\mathrm{R} 7=0.7)$. More explanations in the evolution of food webs in both sites during spring, summer and autumn were reported in the supplement annex.

During winter, the intensification of vertical mixing and the low light condition in both sites were accompanied with a sharp decrease of primary production, which reached the lowest rates registered throughout the year (160-256 $\mathrm{mg} \mathrm{C} \mathrm{m}^{-2} \mathrm{~d}^{-1}$, Fig. 9). These levels were very low compared to the one found in coastal areas. Instead, the bacterial production increased (especially in the Bay) and almost equalled the primary production (bacterial to primary production ratio, $\mathrm{PB}: \mathrm{PP}=0.85-1.07)$. This differed from that observed for the other seasons (PB:PP ratio 0.06-0.21), which were in the range of values found in other coastal areas, such as the Arcachon Bay (0.17, Tortajada et al., 2012: spring), the Bay of Biscay (0.23, Marquis et al., 2007, 2011: spring), and the lagoon of Bizerte (0.23-0.26, Grami et al., 2008: summer). Bacteria supplied $50 \%$ of the $\mathrm{C}$ demand of protozooplankton, which were mainly composed of aloricate ciliates and HNF in both sites during winter (50-70\%, Meddeb et al., submitted). Consequently, the microbivorous activity of protozooplankton increased relatively to their herbivory (Fig. 9 B), while metazooplankton consumed more microphytoplankton than during the other seasons. For these reasons, we were cautious to use only the R7 ratio to identify the dominant food web during winter, because bacteria seemed to play a stronger role in the winter food web than during the other seasons. In this case, another ratio was calculated, the R5 proposed by Sakka Hlaili et al. (2014) to determine the bacterial contribution to the production of potential microzooplankton food. The R5 is defined as the ratio between the net bacterial production to the net production of potential protozoan food (i.e. sum of net production of bacteria, phytoplankton, detritus and doc). R5 values showed that, in all sites, the bacteria contributed largely to the production of potential microzooplankton food during winter $(0.26-0.29)$ than the other seasons $(0.03-0.1)$. The R7 ratio calculated for winter ( 0.20 and 0.28 for the Channel and the Bay, respectively) suggested that the winter structure acted as a multivorous food web, but with the use of the R5 ratio, we preferred to call it "bacterial multivorous food web". In this food web, bacteria and 
microphytoplankton were the main actors and together fuelled the system. This newly defined food web type, which seems to be highly unusual, was not reported in the meta-analysis by Sakka Hlaili et al. (2014), who summarized and defined planktonic food webs from various regions. We propose that the bacterial multivorous food web should be added to the typology proposed by Legendre and Rassoulzadegan, (1995) and Sakka Hlaili et al. (2014) (Fig. 10).

For the determination of this "bacterial multivorous food web", we here propose to researchers and managers, new criteria that they could use to identify quantitatively the trophic pathways that dominate the multivorous food web. The first criterion was the R7 ratio (i.e, picophytoplankton to total phytoplankton production), which separated the three main types of food web: herbivorous $<0.1$, multivorous $0.1-0.6$, and microbivorous $>0.6$. The second criterion was the R5 ratio (i.e. net bacterial production to the net production of potential microzooplankton food), which is used into the multivorous interval and discriminates between the multivorous (low R5 $<0.1$ ) and bacterial multivorous food web (high R5 > 0.2). By using these two ratios in succession, researchers and managers can identify the newly defined food web type, "bacterial multivorous food web".

Despite the impact of many factors on the seasonal evolution of planktonic food webs functioning, it is possible to identify an overall pattern of evolution. The accumulation of nitrates in the water column during winter allows the development of a spring bloom of phytoplankton when light and temperature conditions become more favorable. Thereafter, the mesozooplankton species develop rapidly and the 'herbivorous' food web is set up. This carbon pathway cannot persist in time (Legendre and Rassoulzadegan, 1995). The grazing activity of heterotrophic organisms enriches the pool of carbon and dissolved nitrogen (DOC and DON) and ammonium (excretion). DON promotes remineralization of ammonium by bacteria and their associated predators (protozoa) and a microbial food web settles while the classical herbivorous food web persists, leading to the formation of a 'multivorous food web' (Legendre and Rassoulzadegan 1995). This scenario was observed in the offshore site from the summer to the autumn (Fig. 10B). Phytoplankton communities are dominated by diatoms more suitable for non-limiting conditions of nitrates as was previously observed in other systems (Reynolds 2000, Alves de Souza et al., 2008). Smaller producers dominate when nitrates decrease, which was observed in our inshore station during autumn. Other conditions may favor proliferation of small producers leading to their dominance in relation the total primary production. This leads to the increase of the grazing activity of microzooplankton on the small cells and thus causes the installation of a microbial food web (Fig. 10C). In winter, 
the fall of temperature and light was not favorable to the development of phytoplankton and therefore caused the decrease of the primary production. In this season, nitrogen was still quite low, and bacteria fed on these nutrients and did not use the remineralization process. This led to the increase of the bacterial production which became equal to the primary production accentuating the installation of the "bacterial multivorous food web" (Fig. 10G).

\subsection{Ecosystem indicators and emergent properties}

Ecological ratios (R7 and R5) are useful to discriminate between types of planktonic food webs and to identify "bacterial multivorous food web". In complement, the calculation of Ecological Network Analysis indices are effective tools for characterizing the functioning of the food webs and especially of the new one (Ulanowicz 1986, 1997, Ulanowicz et al., 2009).

For both sites, all ENA indicators have obviously varied over seasons parallel to the change of trophic type (Fig. 8). The ENA variation showed also that there is a seasonal pattern of ecosystem properties, which coincides with specific food web, as illustrated by Fig 11. The highest ecosystem activity, indicated by TST, was observed in spring (2933-3818 mg $\mathrm{C} \mathrm{m}^{-2} \mathrm{~d}^{-1}$ ), when algal blooms occurred and primary production dominating by microphytoplankton (Table 3) resulting to the herbivorous food web. In the opposite, the winter "bacterial multivorous web" showed the lowest activity. The ascendency (A) and the development capacity (DC) are strongly related to the TST (Table 5, Ulanowicz, 2004) and showed the same pattern of variation. The relative ascendency (A/DC) is an essential indicator of the degree of ecosystem organization and specialization (Ulanowicz, 1997; Patrício et al., 2004). The A/DC decreased from spring to summer and then rose in autumn/winter, which perfectly followed the seasonal change in the activity of the observed trophic structures over seasons. In other words, the increase of the amount of carbon circulating (i.e. TST) seemed to favor the direct pathways. Consequently, the carbon flows through few particular flows (bac-pro, mic-pro, pro-met; Fig. 10G) leading to an increase in carbon transfer efficiency and a better organization and specialization (Fig. 11). Other emergent properties of ecosystems (i.e. stability, maturity, resilience...) should also vary among seasons. For example, Legendre and Rassoulzadegan (1995) stated that an herbivorous food web could be considered as a system of low stability, since it is of transient nature and thus inherently unstable. In contrast, the multivorous and microbial food webs have higher stability and thus are longer lasting and will dominate the pelagic environment in most oceans. Our result are coherent with this proposition. Effectively, the FCI and APL indexes 
have increased from spring (FCI: 13-14\%; APL: 2.95-3.20) to summer/autumn (FCI: 1617\%; APL: 3.27-3.33) and then showed the highest value in winter (FCI: 41-46\%; APL: 4.48-5.09). Moreover, during the same succession, the A/DC values have slightly increased, and the maximum value reached is slightly inferior to $60 \%$, hence. With this situation, the maximum possible specialization was not reached, letting a reserve of redundancy, important for the robustness of the food web as underlined by Ulanowicz et al. (2009). This indicates a concomitant increase of ecosystem stability and maturity, when the trophic typology has evolved from the herbivorous web to multivorous and microbial webs and reached the "bacterial multivorous web". This new trophic pathway based on a high heterotrophic bacterial production had the strongest carbon recycling, which lead to a higher retention of carbon inside the ecosystem and then appears to be the most stable and mature.

The $\mathrm{D} / \mathrm{H}$ ratio is often considered as another index that could bring an important information to complete the description of the food web functioning. This ratio has effectively showed a seasonal shift in the food source used by consumers inducing an alternation between a system based on primary production pathway in spring, autumn and winter (lower $\mathrm{D} / \mathrm{H}$ : 0.05-0.48, Fig. 9) and a system based on detrital energy pathways in summer (higher D/H: 0.59-0.66, Fig. 9). In our modelling work, the local information was limited on the detrital pathway toward mesozooplankton. So, detritivory flows were not enough constrained when calculating the unknown flows, which made us uncomfortable on linking the new typology of functioning and $\mathrm{D} / \mathrm{H}$ values. Therefore, more experiments should be done to help limiting detritivory unknown flows before investigating the link between plankton food web typology and $\mathrm{D} / \mathrm{H}$ index.

An important emergent property of each food web, highly related to the internal organization described with the ENA indices, is the distribution of carbon as transfer from the planktonic system, to non-planktonic pelagic consumers or down to the benthic consumers. The fate of biogenic carbon is dependent on the amount of primary production, the size of primary producers and the structure of the food web (Legendre and Rassoulzadegan, 1995; Vézina and Savenkoff, 1999; Legendre and Rivkin, 2002). Herbivorous food webs, based on large producers with high production rate, are considered as having the highest capacity to channel $\mathrm{C}$ to higher pelagic and benthic consumers, whereas in microbial food webs, most organic carbon is expected to be lost through respiration and trophic transfer will be low (Legendre and Rassoulzadegan, 1995, Rivkin et al., 1996; Legendre and Le Fèvre, 1995). Interestingly, a specific situation has been found in winter during which the "bacterial multivorous web" was acting that differs from others seasons (Fig. 6). In spring, summer and 
autumn, the respiration was around 50\% of gpp and a substantial fraction of primary production could reach higher pelagic consumers (21-31\% of gross primary production, gpp). Meanwhile, another significant part of the production sank down to the benthic food web (20$30 \%$ of gpp), mainly due to the downward flow of metazoan faecal pellets (50-72\% of total sinking material). These important proportions of sinking was in accordance to the assumptions made above for the herbivorous and multivorous food webs found in the Channel (during spring/summer) and the Bay (during spring/summer/autumn), but was unexpected for the Channel in autumn. During this season, the microbial pathway was observed and picophytoplankton dominated the primary production, which typically results in carbon leaving the plankton food web mainly through respiration (Legendre and Rassoulzadegan, 1995; Rivkin et al., 1996; Legendre and Le Fèvre, 1995). In our case, it seems that the capacity of the food web to channel carbon to higher trophic levels does not depend so much on the size of the producers, but rather on the amount of primary production, as stated previously (Rivkin et al., 1996, Marquis et al., 2007, 2011). The pronounced capacity of spring, summer and autumn food webs in channeling carbon to pelagic and benthic consumers may result from their high activity, as shown by a high value of TST, but also from the low recycling (FCI) and the low retention of carbon associated with low path length (APL) in the system (Fig. 11).

When the "bacterial multivorous food web" was observed, during winter, most produced carbon was lost by respiration (66-84\% of gpp), leaving a little amount available for higher pelagic consumers (2-2.32\% of gpp, Fig. 6). Obviously, this was a consequence of the functioning of the "bacterial multivorous web", which was characterized by a strong recycling activity and long internal food chains, as supported by the highest values of FCI and APL (Fig. 11). The loss by sinking during winter (14-31\% of gpp) did not differ that much from other seasons, but the sedimentation was mainly due to sinking of phytoplankton (59-75\% of total sinking material). Thus, the winter food web exported carbon to the benthic system, just as the herbivorous pathway, and in the same time showed high cycling activity, as a microbial pathway. This reinforces our suggestion about a new type of functioning during winter, the so-called "bacterial multivorous food web". This understanding of emergent properties determining the functioning of the system and in particular the fate of carbon is primordial as it impacts directly ecosystem services, such as shellfish farming or fishing which are the main activities in both study sites. This is of first importance for environment managers.

\subsection{Ecological indicators, ecosystems health monitoring and management outlook}


The present results highlight the importance of selecting the right indicators and that this directly links with management needs. ENA indices have been proposed as ecosystem health indicators (Niquil et al 2014) and proved to be sensitive to different impacts on marine ecosystems (Baird et al., 2009; Tecchio et al., 2016; Pezy et al., 2017; de la Vega et al., 2018a, b). In line with these former studies, our results showed significant implications of these approaches for the understanding of the ecosystem dynamics and for adaptive management. Some types of food webs can be considered as indicators of trophic status (Fath et al., 2019, Safi et al., 2019) and ecosystem services (Schückel et al., 2018). Thus, the present study appears as a relevant track for managers to develop indicators of health status of ecosystems. Based on the present results, we propose to researchers and managers new criteria (R7 and R5) to consider, in complement to ENA, and that they could use to identify quantitatively the newly defined food web type, "bacterial multivorous food web" which we suggest to be added to the existing typologies of planktonic food webs proposed by Legendre and Rassoulzadegan (1995) and modified by Sakka Hlaili et al. (2014).

Results of ENA analyses contribute to a better knowledge of the impacts of seasonal variations and anthropological pressures on food webs. They also allow defining recommendations for environmental managers and industry in terms of monitoring the effects on marine ecosystems by the limitation of nutrient and pollutant loads in coastal zone and ensuring restoration and increasing ecosystem resilience. Effectively, some ecological indicators, such as TST, A/DC, APL and FCI are already used to examine the impact of anthropization on marine ecosystems. Previous studies have considered TST as an indicator of eutrophication (Niquil et al., 2012; Grami et al., 2008; Scharler and Baird, 2005). Our results reported also very high TST values in spring, related to the high productivity of the ecosystems during this season, and especially to that of the autotrophic organisms (i.e. phytoplankton). The increase in TST could be interpreted as eutrophication and affiliated to the presence of a higher biodiversity of sources of carbon in the ecosystem and also to the proximity of the study stations to sources of nutrient discharges (urban, agricultural and shellfish farming input). Effectively, eutrophication events has been always reported for the Bay and the Channel sites (Sakka Hlaili et al., 2007). The relative ascendency (A/DC), considered as a proxy for maturity, is supposed to decrease with an increase of stress (Ulanowicz, 1997). In our study, we found that A/DC followed trends predicted by this theory. The observed pattern mean that the least disturbed systems (autumn, winter) appeared to be less vulnerable to disturbance, more tightly organized, resistant and more efficient in processing energy (high A/DC) than perturbed systems (spring, summer). In addition, relative 
indices (e.g. A/DC) appeared to be less affected by equilibrium process than the absolute indices (e.g. A). This confirms that the relative information indices appear more suitable for monitoring the effects of anthropogenic impact (as pollution, eutrophication...) on an ecosystem level than the absolute indices (Ulanowicz et al., 2009) and are preferred by many authors (Baird et al., 1991; Baird and Ulanowicz, 1993; Christensen 1995; Monaco and Ulanowicz, 1997; Rybarczyk and Elkaïm 2003; Rybarczyk et al., 2003; Patricio et al., 2004) because it excludes throughputs effects and allows comparison between ecosystems (Heymans et al., 2002).

It was also stated that stressed ecosystems show high FCI (Finn, 1976; Heymans, 2002; Richey et al., 1978; Ulanowicz, 1996; Mann et al., 1989). For example, Baird and Ulanowicz (1993) have shown that FCI index was higher in the most polluted estuary and lower in the less stressed systems, assessing that this index can be viewed as an indicator of pollution. Regarding findings based on chemically polluted and eutrophied ecosystems, FCI values were high in comparison to more pristine systems (Baird et al., 2004; Patricio et al., 2004; Scharler and Baird, 2005) and the structure of cycling changed dramatically between the unimpacted and the eutrophic systems (Patricio et al., 2004), consequently, FCI can be considered as a good candidate index for comparing stress states of many ecosystems. In the Bay and the Channel of Bizerte, chemical contamination by different pollutants has been widely described (Derouiche et al., 2004; Boufahja, 2010; Pringault et al., 2016). Effectively, the high FCI values of the winter (0.41-0.46) and those lower but still high compared to literature values, in other seasons $(0.13-0.17)$, revealed that both systems could be considered as stressed over all the year. Furthermore, for both sites and over all seasons the APL responded to the environmental perturbation to the same gradient as FCI, thus suggesting that either index would be sufficient for evaluating the ecological status of studied ecosystems.

The differences observed in the functioning of the studied sites (the Channel and the Bay of Bizerte) indicate that those ecosystems, strongly impacted by human activities, must be monitored based on several representative sites, chosen regarding their main habitat type and environmental status. In addition, further comparative studies for the same sites should be made in different stations and seasons in term of food web monitoring development perspective. Monitoring programs covering the majority of ecosystem compartments and for the different habitats should be applied. Presently, there are major gaps in knowledge and data, in particular for higher trophic levels such as fish, birds, mammals ... and for lower trophic levels such as meiofauna or benthic diatoms. For this purpose, we advise managers to study and to integrate information about complete trophic systems by recommending a field 
monitoring that covers plankton as well as fish and benthos compartments. Moreover, some other trophic strategies are important to be considered and studied for trophic transfer in planktonic environment (e.g. mixotrophy, parasitism, saprophitism). Integrating all these processes into a single food-web model gathering all carbon flows will allow a complete understanding of the ecosystem functioning. Such an approach is essential for applying a holistic ecosystem management strategy. Finally, we propose the use of well-studied areas as reference sites, selected according to available data (research projects) and existing monitoring programs (sampling takes place regularly, e.g. at least annual basis) for comparison.

\section{Conclusion}

Based on series of physico-chemical and plankton measurements along a seasonal gradient and using the LIM-MCMC approach, this study presents the dynamics and functioning of plankton food webs in inshore and marine waters of SW Mediterranean Sea during all seasons. These waters were characterized by specific environmental and hydrological conditions that were reflected in the food web structures, which showed seasonal dynamics that diverged from the conventional scheme proposed by Legendre and Rassoulzadegan (1995). The herbivorous food web dominated during spring, and showed the highest gross primary production that was largely dominated by microphytoplankton. This coincided with high availability of nutrients and light and stratification of the water column, caused by an increased freshwater inflow in the inshore waters. More surprisingly, the herbivorous food web was also identified during summer, as nutrient and light conditions remained favorable for microphytoplankton production. The multivorous pathway was dominant in the marine site during summer and autumn, when microalgal production decreased and picophytoplankton became more productive. In contrast, the autumn food web in inshore site functioned as microbial pathway, as primary production was mainly dominated by picophytoplankton. The microphytoplankton exhibited the lowest production in autumn, probably due to the decrease of light. The winter situation corresponded to a new type of pathway, the "bacterial multivorous food web" which we suggest can be added to the existing typologies of plankton food webs. In this newly defined food web, bacterial production equalled that of primary production, hence bacteria and microphytoplankton were the main actors that together fuelled the system.

The seasonal change in food webs structure resulted in a shift in the system properties and functioning of the ecosystem summarized in Figure 11. Comparing the ENA indices 
among different seasons showed that the spring trophic pathway (herbivorous food web) was the most active with pronounced total system throughput (TST). In opposite, they showed lower stability in comparison to the systems encountered during summer (multivorous pathway) and autumn (microbial and multivorous pathways), with relatively high cycling activity and path length. The strongest carbon recycling coincided with the "bacterial multivorous food webs" observed in winter. This pathway was the most stable and mature, with pronounced capacity to retain carbon inside the system, leading to low export. The winter ecosystem also seemed to be most organized and specialized, as indicated by the high relative ascendency (A/DC), with a probable more direct carbon pathways (Fig. 11).

Finally, this study propose appropriate indicators and evaluation tools to be used by managers and researchers for the assessment of the structure, functioning and emergent properties of ecosystems in natural and in disturbed conditions. The suggestion is to combine the use of R5 and R7 ratios to identify the newly defined food web type "bacterial multivorous food web" and ENA indices, to distinguish different states of the food web functioning across natural evolution and anthropogenic pressures.

\section{Acknowledgements}

This work was supported by IRD through the JEAI-ECOBIZ and the LIM COSYSMed. MM was financed by an IRD fellowship (ARTS program). The work of Nathalie Niquil on ENA derived indicators for characterizing the functional proprieties of food webs is supported by DEVOTES (DEVelopment Of innovative Tools for understanding marine biodiversity and assessing Good Environmental Status) funded by the European Union under the 7th Framework Programme, 'The Ocean for Tomorrow' Theme (grant agreement no. 308392), www.devotes-project.eu.

We are grateful to the editor and the two anonymous reviewers for their insightful comments and suggestions on an earlier version of the manuscript.

\section{References}

Alekseenko, E., Raybaud, V., Espinasse, B., Carlotti, F., Queguiner, B., Thouvenin, B., Garreau, P., Baklouti, M., 2014. Seasonal dynamics and stoichiometry of the planktonic community in the NW Mediterranean Sea: a 3D modeling approach.Ocean Dyn. 64, 179-207.

Alves-De-Souza, C., Gonzalez, M.T., Iriarte, J.L., 2008. Functional groups in marine phytoplankton assemblages dominated by diatoms in fjords of southern Chile. J. Plank. Res. 30, 1233-1243.

Auger, P.A., Diaz, F., Ulses, C., Estournel, C., Neveux, J., Joux, F., Pujo-Pay, M., Naudin, J.J., 2011. Functioning of the planktonic ecosystem on the Gulf of Lions shelf (NW 
Mediterranean) during spring and its impact on the carbon deposition: a field data and 3-D modelling combined approach. Biogeosciences. 8, 3231-3261.

Auger, P.A., Ulses, C., Estournel, C., Stemmann, L., Somot, S., Diaz, F., 2014. Interannual control of plankton communities by deep winter mixing and prey/predator interactions in the NW Mediterranean: Results from a 30-year 3D modeling study. Prog. Oceanogr. 124, 12-27.

Baird, D., Ulanowicz, R.E., 1989. The seasonal dynamics of the Chesapeake Bay ecosystem. Ecol. Monogr. 59, 329-364

Baird, D., McGlade, J., Ulanowicz, R., 1991. The comparative ecology of six marine ecosystems. Philos. Trans. R. Soc. Lond. B Biol. Sci. 333, 15-29.

Baird, D., Ulanowicz, R.E., 1993. Comparative study on the trophic structure, cycling and ecosystem properties of four tidal estuaries. Marine Ecology Progress Series. 99, 221-237.

Baird, D., Luczkovich, J., Christian, R.R., 1998. Assessment of spatial and temporal variability in ecosystem attributes of the St marks national wildlife refuge, Apalachee bay, Florida. Estuarine. Coast. Shelf Sci. 47, 329-349.

Baird, D., Christian, R.R., Peterson, C.H., Johnson, G.A., 2004. Consequences of hypoxia on estuarine ecosystem function: energy diversion from consumers to microbes. Ecol. Appl. 14, $805 \mathrm{e} 822$.

Baird, D., Fath, B.D., Ulanowicz, R.E., Asmus, H., Asmus, R., 2009. On the consequences of aggregation and balancing of networks on system properties derived from ecological network analysis. Ecol. Model. 220, 3465-3471.

Baird, D., Asmus, H., Asmus, R., 2012. Effect of invasive species on the structure and function of the Sylt-Rømø Bight ecosystem, northern Wadden Sea, over three time periods. Mar. Ecol. Prog. Ser. 462, 143-161.

Béjaoui, B., Harzallah, A., Moussa, M., Chapelle, A., Solidoro, C., 2008. Analysis of hydrobiological pattern in the Bizerte lagoon (Tunisia). Estuar Coast and Shelf Sci. 80, 121129.Bjørnsen, P.K., 1986. Automatic determination of bacterioplankton biomass by image analysis. Appl. Environ. Microbiol. 51, 1199-1204.

Bouchouicha, S.D., Sahraoui, I., Hadj Mabrouk, H., Sakka Hlaili, A., 2012. Seasonal dynamics of genus Alexandrium (potentially toxic dinoflagellate) in the lagoon of Bizerte (North of Tunisia) and controls by the abiotic factors. C R Biol. 335, 406-416.

Boufahja, F., 2010. Approches communautaires et populationnelles de biosurveillance dumilieu marin chez les nématodes libres (lagune et baie de Bizerte, Tunisie). Thèse de doctorat. Faculé des Sciences de Bizerte, Université 7 Novembre Carthage, 422 p.

Bel Hassen, M., Drira, Z., Hamza, A., Ayadi, H., Akrout, F., Issaoui, H., 2008. Summer phytoplankton pigments and community composition related to water mass properties in the Gulf of Gabes. Estuar Coast Shelf Sci. 77, 645-656.

Ben Ismail, S., Sammari, C., Gasparini, G.P., Béranger, K., Brahim, M., Aleya, L., 2012. Water masses exchanged through the Channel of Sicily: evidence for the presence of new water masses on the Tunisian side of the channel. Deep-Sea. Res (I). 63, 65-81.

Calbet, A., Landry, M.R., 2004. Phytoplankton growth, microzooplankton grazing, and carbon cycling in marine system. Limnol. Océanogr. 49, 51-57.

Caroppo, C., 2000. The contribution of picoplankton to community structure in a Mediterranean brackish environment. J. Plankton. Res. 22, 381-397. 
Chaalali, A., Saint-Béat, B., Lassalle, G., Le Loc'h, F., Tecchio, S., Safi, G., Savenkoff, C., Lobry, J., Niquil, N., 2015. A new modeling approach to define marine ecosystems food-web status with uncertainty assessment. Prog. Oceanogr. 135, 37-47.

Christensen, V., 1995. Ecosystem maturity Towards quantification. Ecol. Model. 77, 3-32.

Christensen, V., Pauly, D., 1993. Flow characteristics of aquatic ecosystems. In: Christensen V, Pauly D (eds) Trophic models of aquatic ecosystems. ICLARM (Int Cent Living Aquat Resour Manag). Conf. Proc. 26, 338-353

Christian, R.R., Thomas, C.R., 2003. Network analysis of Nitrogen inputs and cycling in the Neuse River Estuary, North Carolina, USA. Estuar. Coast. 26, 815-828.

Coll, M., Libralato, S., 2012. Contributions of food web modelling to the ecosystem approach to marine resource management in the Mediterranean Sea. Fish. 13, 60-88

Dame, J.K., Christian, R.R., 2007. A statistical test of network analysis: Can it detect differences in food web properties? Ecosystems. 10, 906-923

De Laender, F., van Oevelen, D., Soetaert, K., Middelburg, J.J., 2010. Carbon transfer in a herbivore-dominated and a microbial loop-dominated pelagic food web: spring and summer in the southern Barents Sea. Mar. Ecol. Prog. Ser. 398, 93-107.

de la Vega, C., Horn, S., Baird, D., Hines, D., Borrett, S., Jensen, L.F., Schwemmer, P., Asmus, R., Siebert, U., Asmus, H., 2018a. Seasonal dynamics and functioning of the SyltRømø Bight, northern Wadden Sea. Estuar. Coast. Shelf Sci. 203, 100-118.

de la Vega, C., Schückel, U., Horna, S., Krönck, I., Asmus, R., Asmus, H., 2018b. How to include ecological network analysis results in management? A case study of three tidal basins of the Wadden Sea, south-eastern North Sea. Ocean Coastal Manag. 163, 401-416

Donali, E., Olli, K., Heiskanen, A.S., Andersen, T., 1999. Carbon flow patterns in the planktonic food web of the Gulf of Riga, the Baltic Sea: a reconstruction by the inverse method. J. Mar. Syst. 23, 251-268.

Fath, B.D., Asmus, H., Asmus, R., Baird, D., Borrett, S.R., de Jonge, V.N., Ludovisi, A., Niquil, N., Scharler, U.M., Schückel, U., Wolff, M., 2019. Ecological network analysis metrics: The need for an entire ecosystem approach in management and policy. Ocean. Coast. Manage. 174, 1-14.

Finn, J.T., 1976. Measures of ecosystem structure and function derived from analysis of flows. J. Theor. Biol. 56, 363-380.

Fortier, L., Le Fèvre, J., Legendre, L., 1994. Export of biogenic carbon to fish and to the deep ocean: the role of large planktonic microphages. J. Plankton. Res. 16, 809-839.

Giannakourou, T., Kanellopoulou, M., Siokou, F., and Pitta., 2014. Temporal variability of the microbial food web (viruses to ciliates) under the influence of the Black Sea Water inflow (N. Aegean, E. Mediterranean). Mediterr. Mar. Sci. 15, 769-780. 
Grami, B., Niquil, N., Sakka Hlaili, A., Gosselin, M., Hamel, D., Hadj Mabrouk, H., 2008. The plankton food web of the Bizerte Lagoon (South-Western Mediterranean): II. Carbon steady state modelling using inverse analysis. Estua. Coast. Shelf. Sci. 79, 101-113.

Grami, B., Rasconi, S., Niquil, N., Jobard, M., Saint Béat, B., 2011. Functional effects of parasites on food web properties during the spring diatom bloom in Lake Pavin: a linear inverse modeling analysis. Plos. One. 6, 23273.

Grattepanche, J.D., Vincent, D., Breton, E., Christaki, U., 2011. Microzooplankton herbivory during the diatom Phaeocystis spring succession in the eastern English Channel. J. ExpMar Bio. Ecol. 404, 87-97.

Hafferssas, A., Seridji, R., 2010. Relationships between the hydrodynamics and changes in copepod structure on the Algerian coast. Zool. Stud. 49, 353-366.

Harzallah, A., Brahim, M., Sammari, C., Koutitonsky, V., 2003. Water salinity and heat budgets in the lagoon of Bizerte estimated from observations and model simulation. Proceedings of 3rd JICA.

Hattab, T., Ben Rais Lasram, F., Albouy, C., Romdhane, M.S., Jarboui, O., Halouani, G., Cury,

P., Le Loc'h, F., 2013. An ecosystem model of an exploited southern Mediterranean shelf region (Gulf of Gabes, Tunisia) and a comparison with other Mediterranean ecosystem model properties. J. Mar. Sys. 128,159-174.

Herrmann, M., Diaz, F., Estournel, C., Marsaleix, P., Ulses, C., 2013. Impact of atmospheric and oceanic interannual variability on the Northwestern Mediterranean Sea pelagic planktonic ecosystem and associated carbon cycle. J. Geophys. Res. Oceans. 118, 5792-5813.

Heymans, J.J., Ulanowicz, R.E., Bondavalli, C., 2002. Network analysis of the South Florida Everglades graminoid marshes and comparison with nearby cypress ecosystems. Ecol. Model. $149,5-23$.

Heymans, J.J., Coll, M., Libralato, S., Morissette, L., Christensen, V., 2014. Global patterns in ecological indicators of marine food webs: a modelling approach. Plos. One. 9, 95845.

Hillebrand, H., Dürselen, C.D., Kirschtel, D., Pollingher, U., Zohary, T., 1999. Biovolume calculation for pelagic and benthic microalgae. J. Phycol. 35, 403-424.

Hines, D.E., Lisa, J.A., Song, B., Tobias, C.R., Borrett, S.R., 2015. Estimating the effects of seawater intrusion on an estuarine nitrogen cycle by comparative network analysis. Mar. Ecol. Prog. Ser. 524, 137-154

Horn, S., de la Vega, C., Asmus, R., Schwemmer, P., Enners, L., Garthe, S., Binder, K., Asmus, H., 2017. Interaction between birds and macrofauna within food webs of six intertidal habitats of the Wadden Sea. PLoS One. 12, 0176381.

Huertas, I.E., Navarro, G., Rodriguez-Gàlvez, S., Lubiaàn, L.M., 2006. Temporal patterns of carbon dioxide in relation to hydrological conditions and primary production in the northeastern shelf of the Gulf of Cadiz (SW spain). Deep Sea Res Part (II): Topical Studies in Oceanography. 53, 1344-1362. 
Irigoien, X., Flynn, K.J., Harris, R.P., 2005. Phytoplankton blooms: a 'loophole' in microzooplankton grazing impact. J. Plankton. Res. 27, 313-321.

Johnson, G.A., Niquil, N., Asmus, H., Bacher, C., Asmus, R., Baird, D., 2009. The effects of aggregation on the performance of the inverse method and indicators of network analysis. Ecol. Model. 220, 3448-3464.

Knap, A.H., Michael, A.F., Dow, R.L., Johnson, R.J., Gundersen, K., Sorensen, J.C., Close, A.R., Howse, F.A., Hammer, M., Bates, N., Doyle, A., Waterhouse, T., 1993. BATS Methods Manual. US Joint Global Ocean Flux Planning. Office, Woods Hole Massachusetts, A 3, 1108.

Knap, A., Michaels, A., Close, A., Ducklow, H., Dickson, A., 1996. Protocols for the Joint Global Ocean Flux Study (JGOFS) Core Measurements, JGOFS Report No. 19, 170 pp. Reprint of the IOC Manuals and Guides No 29, UNESCO 1994.

Lafferty, K.D., Hechinger, R.F., Shaw, J.C., Whitney, K., Kuris, A.M., 2006. Food webs and parasites in salt marsh ecosystem. Chap. 9, Disease ecology: community structure and pathogen dynamics, Oxford University Press. 119-134.

Lafferty, K.D., Allesina, S., Arim, M., Briggs, C.J., Leo, G., 2008. Parasites in food webs: the ultimate missing links. Ecol. Letters. 11, 533-546.

Landry, M.R., Hassett, R.P., 1982. Estimating the Grazing Impact of Marine Microzooplankton. Mar. Biol. 67, 283-288.

Lassalle, G., Lobry, J., Le Loc'h, F., Bustamante, P., Certain, G., Delmas, D., Dupuy, C., Hily, C., Labry, C., Le Pape, O., Marquis, E., Petitgas, P., Pusineri, C., Ridoux, V., Spitz, J., Niquil, N., 2011. Lower trophic levels and detrital biomass control the Bay of Biscay continental shelf food web: Implications for ecosystem management. Prog. Oceanogr. 91, $561-575$.

Legendre, L., Rassoulzadegan, F., 1995. Plankton and nutrient dynamics in marine waters. Ophelia. 41, 153-172.

Legendre, L., Le Fevre, J., 1996. Microbial food webs and the export of biogenic carbon in oceans. Aquat. Microb. Ecol. 9, 69-77.

Legendre, L., Rivkin, R. B., 2002. Fluxes of carbon in the upper ocean: regulation by foodweb control nodes. Mar. Ecol. Prog. Ser. 242, 95-109.

Leguerrier, D., Degré, D., Niquil, N., 2007. Network analysis and inter-ecosystem comparison of two intertidal mudflat food webs (Brouage Mudflat and Aiguillon Cove, SW France). Estuar. Coast. Shelf. Sci. 74, 403-418.

Lund, J.W.G., Kipling, C., Le Cren, E.D., 1958. The inverted microscope method of estimating algal numbers and statistical basis of estimations by counting. Hydrobiologia. $11,143-170$. 
Mann, K.H., Field, J.G., Wulff, F., 1989. Network analysis in marine ecology: an assessment. Coastal and Estuarine Studies. 32, 259-282.

MacIsaac, E.A., Stockner, J.G., 1993. Enumeration of phototrophic picoplankton by autofluorescence microscopy. In: Kemp, P.F., Sherr, B.F., Sherr, E.B., Cole, J.J. (Eds.), Handbook of Methodology in Aquatic Microbial Ecology. Lewis Publishers Boca Raton FL, pp. 187-197.

Marquis, E., Niquil, N., Delmas, D., Hartmann, H.J., Bonnet, D., Carlotti, F., Herbland, A., Labry, C., Sautour, B., Laborde, P., Vézina, A., Dupuy, C., 2007. Inverse analysis of the planktonic food web dynamics related to phytoplankton bloom development on the continental shelf of the Bay of Biscay, French coast. Estuar. Coast. Shelf. Sci. 73, 223-235.

Marquis, E., Niquil, N., Vézina, A. F., Petitgas, P., Dupuy, C., 2011. Influence of planktonic foodweb structure on a system's capacity to support pelagic production: an inverse analysis approach. J. Mar. Sci. 68, 803-812.

Meddeb, M., Grami B., Chaalali, A., Haraldsson, M., Niquil, N., Pringault, O., Sakka Hlaili, A., 2018. Plankton food-web functioning in anthropogenically impacted coastal waters (SW Mediterranean Sea): An ecological network analysis. Prog. Oceanogr. 162, 66.82.

Meddeb, M., Grami, B., Gueroun, S.K.M., Mejri, K., Daly Yahia, M.N., Chalghaf, M., Ksouri, J., Pringault, O., Sakka Hlaili, A., (Submitted). Trophic role of microzooplankton and mesozooplankton in structuring the planktonic food web in SW Mediterranean coastal waters: a seasonal variation. Limnol. Oceanogr.

Millot, C., 1987. Circulation in the Western Mediterranean Sea. Oceanol. Acta.10, 143-149.

Millot, C., 1999. Circulation in the Western Mediterranean Sea. J. Mar. Syst. 20. 423-442.

Monaco, M.E., Ulanowicz, R.E., 1997. Comparative ecosystem trophic structure of three U.S. mid-Atlantic estuaries. Mar. Ecol. Prog. Ser.161, 239-254.

Mullin, M.M., Sloan, P.R., Eppley, R.W., 1966. Relationship between carbon content, cell volume and area in phytoplankton. Limnol.Oceanogr.11, 307-311.

Niquil, N., Jackson, G.A., Legendre, L., Delesalle, B., 1998. Inverse model analysis of the planktonic food web of Takapoto Atoll (French Polynesia). Mar. Ecol. Progr. Ser. 165,17-29.

Niquil, N., Pouvreau, S., Sakka, A., Legendre, L., Addessi, L., Le Borgne, R., Charpy, L., Delesalle, B., 2001. Trophic web and carrying capacity in a pearl oyster farming lagoon (Takapoto, French Polynesia). Aquat. Liv. Res. 14, 165-174.

Niquil, N., Kagami, M., Urabe J, Christaki, U., Viscogliosi, E., Sime-Ngando, T., 2011. Potential role of fungi in plankton food web functioning and stability: a simulation analysis based on Lake Biwa inverse model. Hydrobiologia. 659, 65-79.

Niquil, N., Chaumillon, E., Johnson, G.A., Bertin, X., Grami, B., David, V., Bacher, C., Asmus, H., Baird, D., Asmus, R., 2012. The effect of physical drivers on ecosystem indices derived from ecological network analysis: Comparison across estuarine ecosystems. Estuar. Coast. Shelf. Sci. 108, 132-143. 
Niquil, N., Baeta, A., Marques, J.C., Chaalali, A., Lobry, J., Patrício, J., 2014. Reaction of an estuarine food web to disturbance: lindeman's perspective. Mar. Ecol. Prog. Ser. 512, 141154.

Nixon, S.W., 1995. Coastal marine eutrophication: a definition, social causes and future concerns. Ophelia. 41, 199-219.

Olsen, Y., Reinertsen, H., Vadstein, O., Andersen, T., Gismervik, I., Duarte, C., Agusti, S., Stibor, H., Sommer, U., Lignell, R., Tamminen, T., Lancelot, C., Rousseau, V., Hoell, E., Sanderud, K.A., 2001. Comparative analysis of food webs based on flow networks: effects of nutrient supply on structure and function of coastal plankton communities. Cont. Shelf. Res. 21, 2043-2053.

Pace, M.L., Glasser, J.E., Pomeroy, L.R., 1984. A simulation analysis of continental shelf food webs. Mar. Biol. 82, 47-63

Parsons, T.P., Maita, Y., Lalli, C.M., 1984. A manuel of Chemical and Biological Methods for Seawater analysis. Pergamon Press, Oxford, England.1, 173.

Patrício, J., Ulanowicz, R., Pardal, M.A., Marques, J.C., 2004. Ascendency as an ecological indicator: a case study of estuarine pulse eutrophication. Estuar. Coast. Shelf. Sci. 60, 23-35.

Pezy, J.P., Raoux, A., Marmin, S., Balay, P., Niquil, N., Dauvin, J.C., 2017. Before-After analysis of the trophic network of an experimental dumping site in the eastern part of the Bay of Seine (English Channel). Mar. Poll. Bull. 118, 101-111.

Pringault, O., Lafabrie, C., Avezac, M., Bancon-Montigny, C., Carre, C., Chalghaf, M., Delpoux, S., Duvivier, A., Elbaz-Poulichet, F., Gonzalez, C., Got, P., Leboulanger, C., Spinelli, S., Sakka Hlaili, A., Bouvy, M., 2016. Consequences of contaminant mixture on the dynamics and functional diversity of bacterioplankton in a southwestern Mediterranean coastal ecosystem. Chemosphere. 144, 1060-1073.

Putland, J.N., R.L., Iverson., 2007. Microzooplankton: major herbivores in an estuarine planktonic food web. Mar. Ecol. Progr. Ser. 345, 67-73.

Rasconi, S., Grami, B., Niquil, N., Jobard, M., Sime-Ngando, T., 2014. Parasitic chytrids sustain zooplankton growth during inedible algal bloom. Front. Microbiol. 5, 1-19.

Rasconi, S., Winter, K., Kainz, MJ., 2017. Temperature increase and fluctuation induce phytoplankton biodiversity loss Evidence from a multi-seasonal mesocosm experiment. Ecol. Evol. 7, 2936-2946.

Richardson, T.L., Jackson, G.A., Burd, A.B., 2003. Planktonic food web dynamics in two contrasting regions of Florida Bay. U.S. Bulletin of Marine Science. 73, 569-591.

Richardson, T.L., Jackson, G.A., Ducklow, H.W., Roman, M.R., 2004. Carbon fluxes through food webs of the eastern equatorial Pacific: an inverse approach. Deep Sea Research I. 51, $1245-1274$. 
Richey, J.E., Wissmar, R.C., Devol, A.H., Likens, G.E., Eaton, J.S., Wetzel, R.G., Odum, W.E., Johnson, N.M., Loucks, O.L., Prentki, R.T., Rich, PH., 1978. Carbon flow in four lake ecosystems: a structural approach. Science. 202,1183-6.

Rivkin, R.B., Legendre, L., Deibel, D., Tremblay, J.E., Klein, B., Crocker, K., Roy, S., Silverberg, N., Lovejoy, C., Mesplé, F., Romero, N., Anderson, M.R., Mattews, P., Savenkoff, C., Vézina, A., Theriault, J.C., Wesson, J., Bérubé, C., Ingram, R.G., 1996. Vertical flux of biogenic carbon in the ocean: is there food web control?. Science. 272, 11631166.

Romano, J., Kromrey, J.D., Coraggio, J., Skowronek, J., 2006. Appropriate statistics for ordinal level data: Should we really be using t-test and cohen's d for evaluating group differences on the NSSE and other surveys?, in: Annual meeting of the Florida Association of Institutional Research.

Rybarczyk, H., Elkaim, B., 2003. An analysis of the trophic network of a macrotidal estuary: the Seine Estuary (Eastern Channel, Normandy, France). Estuar. Coast. Shelf. Sci. 58, 775791.

Rybarczyk, H., Elkaim, B., Ochs, L., Loquet, N., 2003. Analysis of the trophic network of a macrotidal ecosystem: the Bay of Somme (Eastern Channel). Estuar. Coast. Shelf. Sci. 58, 405-421.

Ryther, H., 1969. Photosynthesis and fish production in the sea. Science. 166, 72-76.

Safi, G., Giebels, D., Arroya, N.L., Heymans, J.J., Preciado, I., Raoux, A., Schückel, U., Tecchio, S., de Jonge, V.N., Niquil, N., 2019. Vitamine ENA: a framework for the development of ecosystem-based indicators for decision- makers. Ocean. Coast. Manage. 174, $116-130$.

Sahraoui, I., Sakka Hlaili, A., Hadj Mabrouk, H., Léger, C., Bates, S.S., 2009. Blooms of the diatom genus Pseudo-nitzschia H. Peragallo in Bizerte Lagoon (Tunisia, SW Mediterranean). Diatom. Res. 24, 175-190.

Sahraoui, I., Grami, B., Bates, S.S., Bouchouicha, D., Chikhaoui, M.A., Hadj Mabrouk, H., Sakka Hlaili, A., 2012. Response of potentially toxic Pseudo-nitzschia (Bacillariophyceae) populations and domoic acid to environmental conditions in a eutrophied, SW Mediterranean coastal lagoon (Tunisia). Est. Coast. Shelf. Sci. 102-103, 95-104.

Sakka Hlaili, A., Grami, B., Niquil, N., Gosselin, M., Hamel, D., Hadj Mabrouk, H., 2008. The Planktonic food web of the Bizerte Lagoon (South-western Mediterranean): I. Spatial distribution under different human pressures. Estuar. Coast. Shelf. Sci. 78, 61-77.

Sakka Hlaili, A., Niquil, N., Legendre, L., 2014. Planktonic food webs revisited: Reanalysis of results from the linear inverse approach. Prog. Oceanogr. 120, 216-229.

Sankar, R.S., Padmavati, G., 2012. Species Composition, Abundance and Distribution of Phytoplankton in the Harbour Areas and Coastal Waters of Port Blair, South Andaman. Inter. J. Oceanogr. Mar. Ecol. Syst. 1, 76-83. 
Saint-Béat, B., Vézina, A.F., Asmus, R., Asmus, H., Niquil, N., 2013. The mean function provides robustness to linear inverse modelling flow estimation in food webs: a comparison of functions derived from statistics and ecological theories. Ecol. Model. 258, 53-64.

Scharler, U.M., Baird, D., 2005. A comparison of selected ecosystem attributes of three South African estuaries with different freshwater inflow regimes, using network analysis. J. Mar. Syst. 56, 283-308.

Schückel, U., Kröncke, I., Baird, D., 2015. Linking long-term changes in trophic structure and function of an intertidal macrobenthic system to eutrophication and climate change using ecological network analysis. Mar. Ecol. Prog. Ser. 536, 25-38

Schückel, U., de Jonge, V., Ludovisi, A., Giebels, D., Horn, S., Niquil, N., Asmus, H., Asmus, R., Igor, E., Georges, S., Scharler, U., 2018 Use of coastal and estuarine food web models in policy making and management: the need for an entire approach, $26 \mathrm{pp}$.

Siokou-Frangou, I., Bianchi, M., Christaki, U., Christou, E.D., Giannakourou, A., Gotsis, O., Ignatiades, L., Pagou, K., Pitta, P., Psarra, S., Souvermezoglou, E., Van Wambeke, F., Zervakis, V., 2002. Carbon flow in the planktonic food web along a gradient of oligotrophy in the Aegean Sea (Mediterranean Sea). J. Mar. Sys. 33-34, 335-353.

Siokou-Frangou, I., Christaki, U., Mazzocchi, M.G., Montresor, M., d'Alcala, M.R., Vaqué, D., Zingone, A., 2010. Plankton in the open Mediterranean Sea. a review. Biogeoscience. 7, $1543-1586$.

Slaughter, A.M., Bollens, S.M., Bollens, G. R., 2006. Grazing impact of mesozooplankton in an upwelling region off northern California, 2000-2003. Deep-Sea. Res (II). 53, 3099-3115.

Søndergaard, M., Jensen, L.M., Ertebrjerg, G., 1991. Picoalgae in Danish coastal waters during summer stratification. Mar. Ecol. Prog. Ser. 79, 139-149.

Steinberg, D.K., Carlson, C.A., Bates, N.R., Goldthwait, S.A., Madin, L.P., Michaels, A.F., 2000. Zooplankton vertical migration and the active transport of dissolved organic and inorganic carbon in the Sargasso Sea. Deep-Sea Res (I). 47, 137-158.

Tecchio, S., Coll, M., Sardà, F., 2015. Structure, functioning, and cumulative stressors of Mediterranean deep-sea ecosystems. Prog. Oceanogr. 135, 156-167.

Tecchio, S., Chaalali, A., Raoux, A., Tous Rius, A., Lequesne, J., Girardin, V., Lassalle, G., Cachera, M., Riou, P., Lobry, J., Dauvin, J.C., Niquil, N., 2016. Evaluating ecosystem-level anthropogenic impacts in a stressed transitional environment: The case of the Seine estuary. Ecol. Indic. 61, 833-845.

Thingstad, T.F., Rassoulzadegan, F., 1999. Conceptual models for the biogeochemical role of the photic zone microbial food web, with particular reference to the Mediterranean Sea. Prog. Oceanogr. 44, 271-286

Tortajada, S., Niquil, N.,Blanchet, H., Grami, B., Montanie, H.,David, V.,Gle, C., Saint-Beat, B., Johnson, G.A., Marquis, E.,Del Amo, Y.,Dubois, S.,Vincent, D., Dupuy, C.,Jude, F., 
Hartmann, H.J.,Sautour, B.,2012. Network analysis of the planktonic food web during the spring bloom in a semi enclosed lagoon (Arcachon, SW France).Acta. Oecologica. 40, 40-50.

Thomas, C.R., Christian, R.R., 2001. Comparison of nitrogen cycling in salt marsh zones related to sea-level rise. Mar. Ecol. Prog. Ser. 221, 1-16.

Turner, J.T., Levinsen, H., Nielsen, T.G., Hansen, B.W., 2001. Zooplankton feeding ecology: grazing on phytoplankton and predation on protozoans by copepod and barnacle nauplii in Disko Bay, West Greenland. Mar. Ecol. Progr. Ser. 221, 209-219.

Uitto, A., Heiskanen, A.S., Lignell, R., Autio, R., Pajuniemi, R., 1997. Summer dynamics of the coastal planktonic food web in the northern Baltic Sea. Mar. Ecol. Prog. Ser. 151, 27-41.

Ulanowicz, R.E., 1980. An hypothesis on the development of natural communities. Journal of Theoretical Biology 85, 223-245.

Ulanowicz, R.E., 1986. Growth and Development: Ecosystems Phenomenology. Springer Science \& Business Media.

Ulanowicz, R.E., 1992. Ecosystem Health and Trophic Flow Networks. Ecosystem Health: New Goals for Environmental Management. Island Press, Washington, DC, pp. 190-206

Ulanowicz, R.E., 1996. Trophic flow networks as indicators of ecosystem stress. In: Polis GA, Winemiller KO, Eds. Food webs: integration of patterns and dynamics New York. Chapman and Hall. 358-68.

Ulanowicz, R.E., 1997. Ecology, the Ascendent Perspective Columbia University Press, New York.

Ulanowicz, R. E., 2003. Some steps toward a central theory of ecosystem dynamics. Comput. Biol. Chem. 27, 523-530

Ulanowicz, R.E., 2004. Quantitative methods for ecological network analysis. Comput. Biol. Chem. 28, 321-339.

Ulanowicz, R.E., Goerner, S.J., Lietaer, B., Gomez, R., 2009. Quantifying sustainability: Resilience, efficiency and the return of information theory. Ecol. Complex. 6, 27-36.

Van den Meersche, K., Soetaert, K., van Oevelen, D., 2009. xsample (): An R function for sampling linear inverse problems. J. Stat. Softw. 30, 1-15.

Vajravelu, M., Martin, Y., Ayyappan, S., Mayakrishnan, M., 2017. Seasonal influence of physico-chemical parameters on phytoplankton diversity, community structure and abundance at Parangipettai coastal waters, Bay of Bengal, South East Coast of India. Oceanologia. (in press).

Vargas, C.A., Martínez, R., Cuevas, L., Pavez, M., Cartes, C., González, H., Escribano, R., Daneri, G., 2007. The relative importance of microbial and classical food webs in a highly productive coastal upwelling area. Limnol. Oceanogr. 52, 1495-1510. 
Vasconcellos, M., Mackinson, S., Sloman, K., Pauly, D., 1997. The stability of trophic massbalance models of marine ecosystems: A comparative analysis. Ecol. Model. 100, 125134.

Vézina, A.F., Platt, T., 1988. Food web dynamics in the ocean. I. Best estimates using inverse Methods. Mar. Ecol. Prog. Ser. 42, 269-287.

Vézina, A.F., Pace, M.L., 1994. An inverse model analysis of planktonic food webs in experimental lakes. Can. J. Fish. Aquat. Sci. 51, 2034-2044.

Vézina, A.F., Savenkoff, C., 1999. Inverse modeling of carbon and nitrogen flows in the pelagic food web of the northeast subarctic Pacific. Deep-Sea. Res (II). 46, 2909-2939.

Vézina, A.F., Savenkoff, C., Roy, S., Klein, B., Rivkin, R., Therriault, J.-C., Legendre, L., 2000. Export of biogenic carbon and structure and dynamics of the pelagic food web in the Gulf of St, Lawrence. Part 1, Seasonal variations. Deep-Sea. Res (II). 47, 585-607.

Vézina, A.F., Pahlow, M., 2003. Reconstruction of ecosystem flows using inverse methods: how well do they work? J. Mar. Syst. 40, 55-77.

Wulff, F. and Ulanowicz, R.E., 1989. Comparative anatomy of the Baltic Sea and Chesapeake ecosystems. In: F. Wulff, J.G. Field and K.H. Mann (Editors), Network Analysis in Marine Ecosystems. Springer-Verlag, Heidelberg, pp. 232-258

Zaaboub, N., Martins, M.V.A., Dhib, A., Béchir, B., Galgani, F., El Bour, M., Aleya, L., 2015. Accumulation of trace metals in sediments in a Mediterranean Lagoon: usefulness of metal sediment fractionation and elutriate. Environ. Pollut. 207, 226-237.

Zervoudaki, S., Christou, E.D., Assimakopoulou, G., Örek, H., Gucu, A.C., Giannakourou, A., Pitta, P., Terbiyik, T., Yücel, N., Moutsopoulos, T., Pagou, K., Psarra, S., Özsoy, E., Papathanassiou, E., 2011. Copepod communities, production and grazing in the Turkish Straits System and the adjacent northern Aegean Sea during spring. J. Mar. Syst. 86, 45-56.

Zrafi-Nouira, I., Khedir-Ghenim, Z., Zrafi, F., Bahri, R., Cheraeif, I., Rouabhia, M., 2008. Hydrocarbon pollution in the sediment from the Jarzouna-Bizerte coastal area of Tunisia (Mediterranean Sea). Bulletin of Environment. 
Figures



Download : Download high-res image (374KB)

Download : Download full-size image

Fig. 1. Location of the two study stations in the Channel (inshore station; C) and the Bay of Bizerte (marine station; B). 


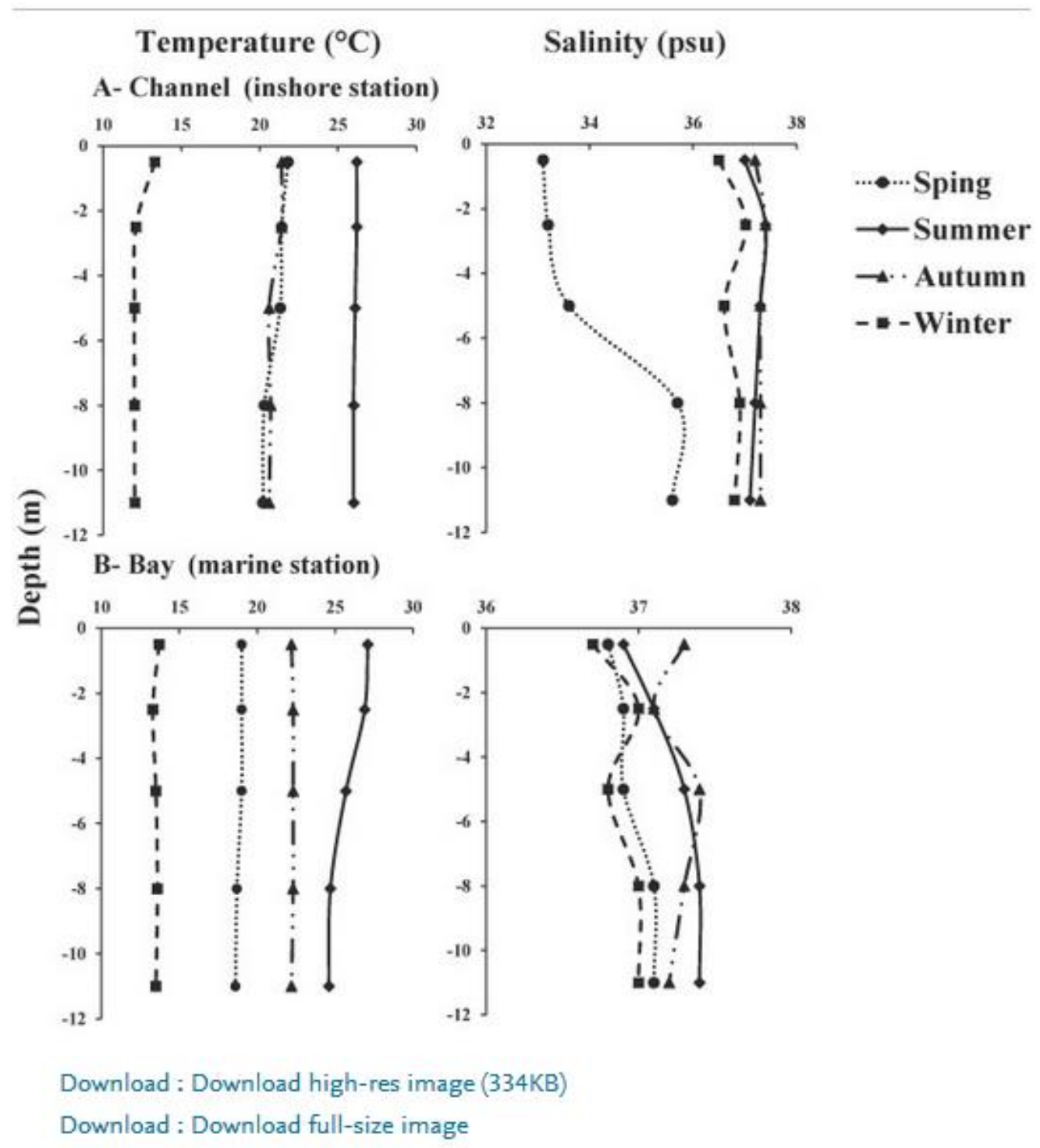

Fig. 2. Temperature and salinity profiles of the water column in the Channel (inshore station) and the Bay (marine station) over the seasons. 


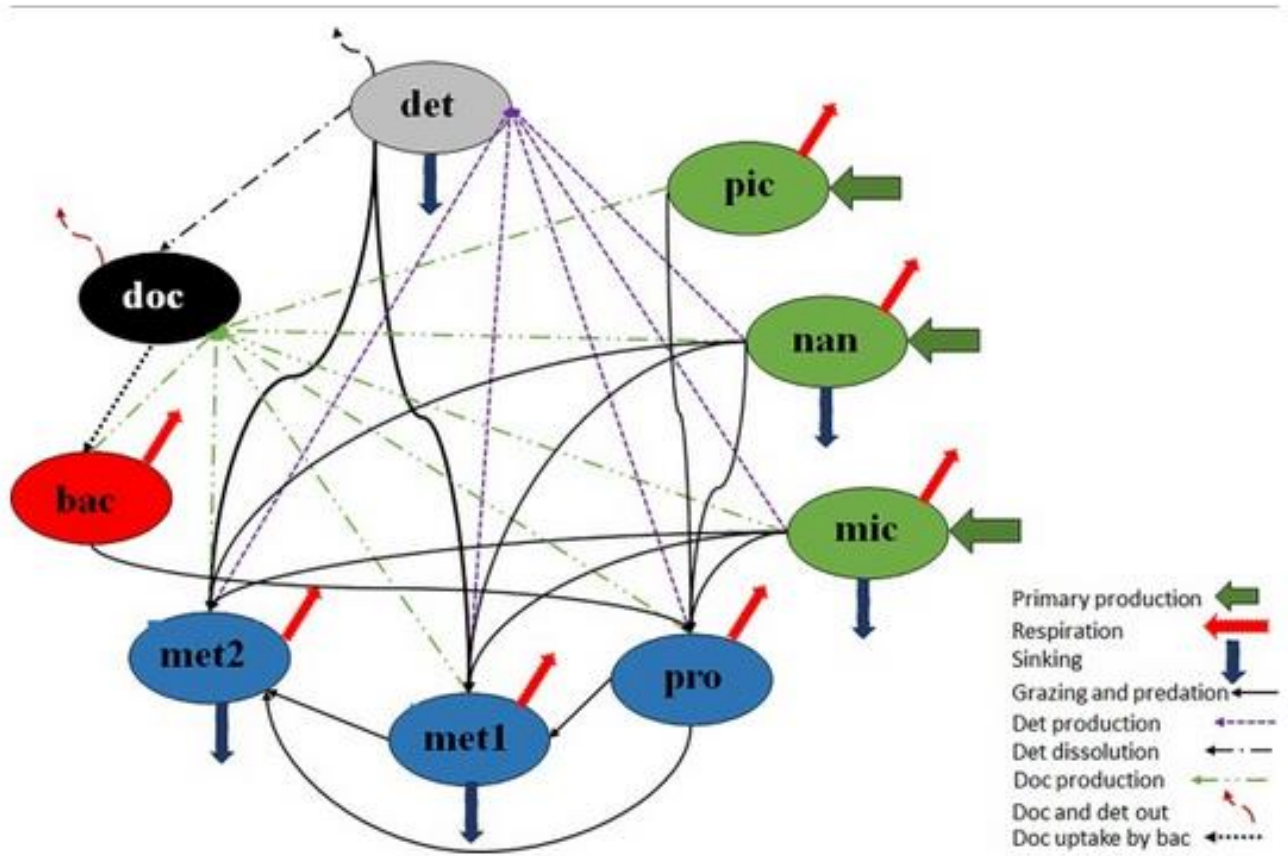

Download : Download high-res image (294KB)

Download : Download full-size image

Fig. 3. A priori model used to build the eight planktonic food web systems. Heterotrophic bacteria = bac, picophytoplankton $<2 \mu \mathrm{m}=$ pic, nanophytoplankton 2-10 $\mathrm{m}$ = nan, microphytoplankton $20-200 \mu \mathrm{m}=\mathrm{mic}$, protozooplankton $<200 \mu \mathrm{m}=$ pro, metazooplankton $200-700 \mu \mathrm{m}=$ metl, metazooplankton $>700 \mu \mathrm{m}=$ met2, dissolved organic carbon $=$ doc and $\underline{\text { detritus }}=$ det. 


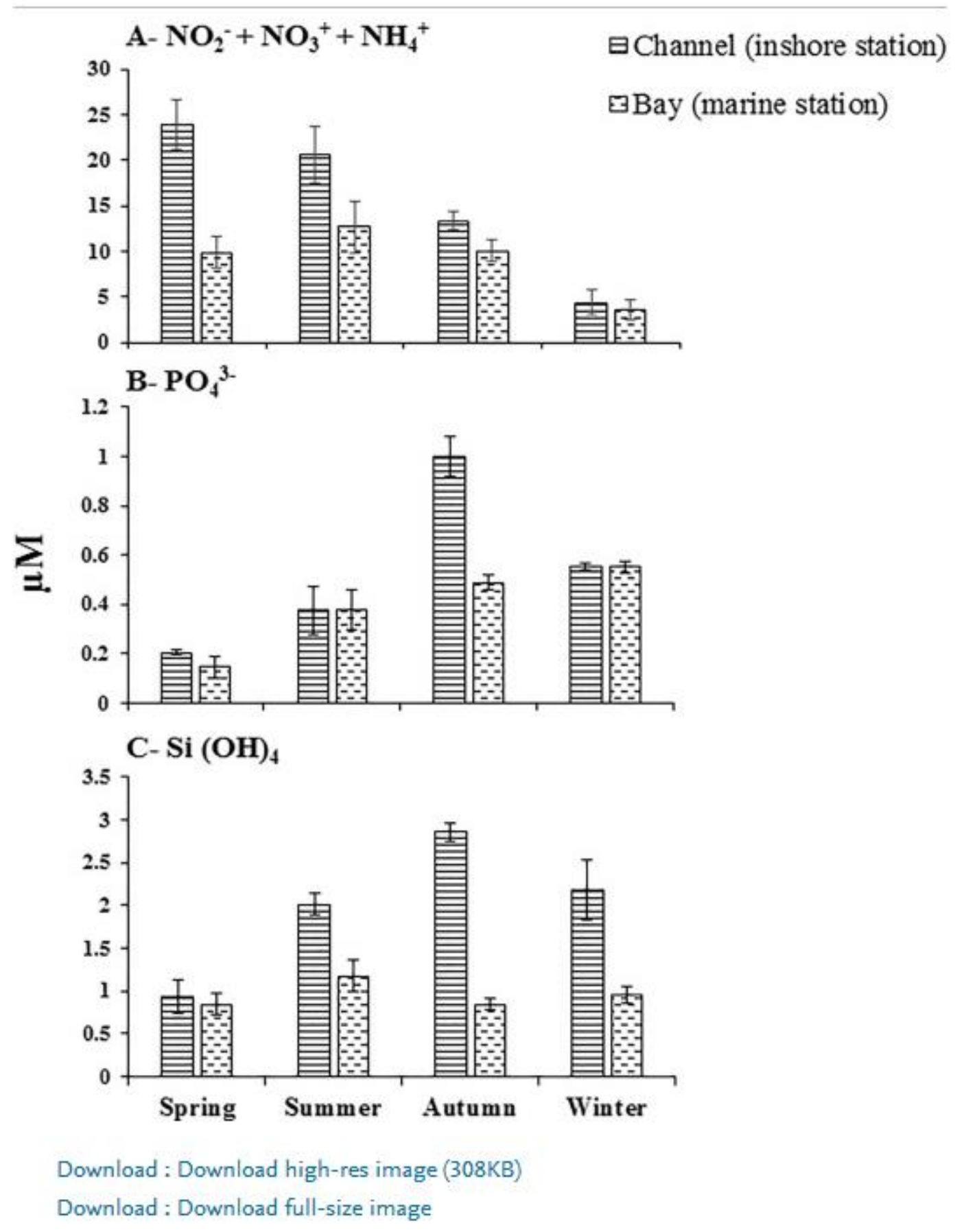

Fig. 4. Average concentrations of nutrients $(\mu \mathrm{M})$ in the Channel (inshore station) and the Bay (marine station) over the seasons (average $\pm \mathrm{SD}, \mathrm{n}=3$ ). 


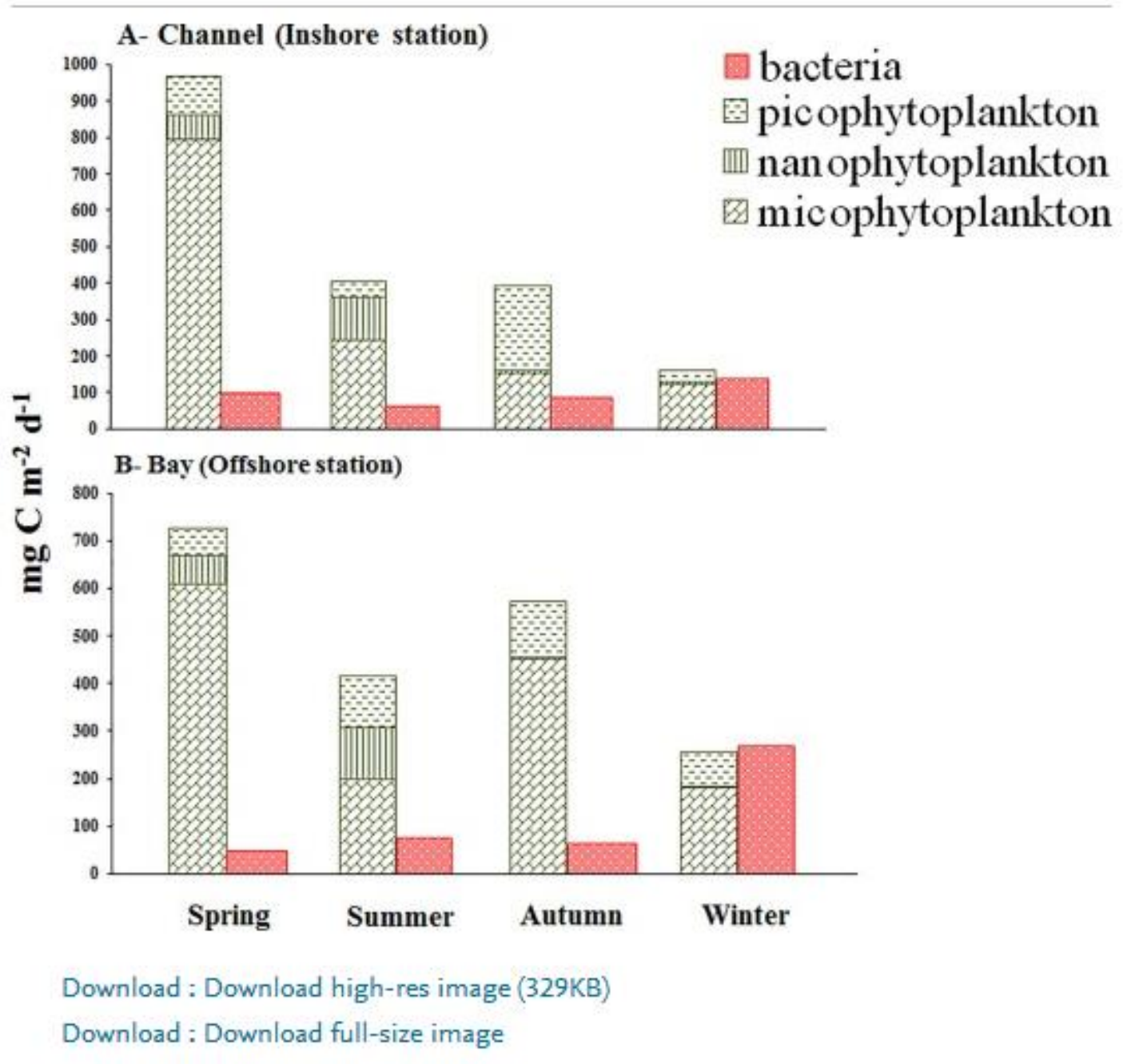

Fig. 5. Production ( $\left.\mathrm{mg} \mathrm{C} \mathrm{m}^{-2} \mathrm{~d}^{-1}\right)$ of the three phytoplankton size-classes (mic, nan and pic) and the heterotrophic bacteria (bac) in the inshore and marine stations over the seasons. The two bars refer to autotrophic vs heterotrophic production. 


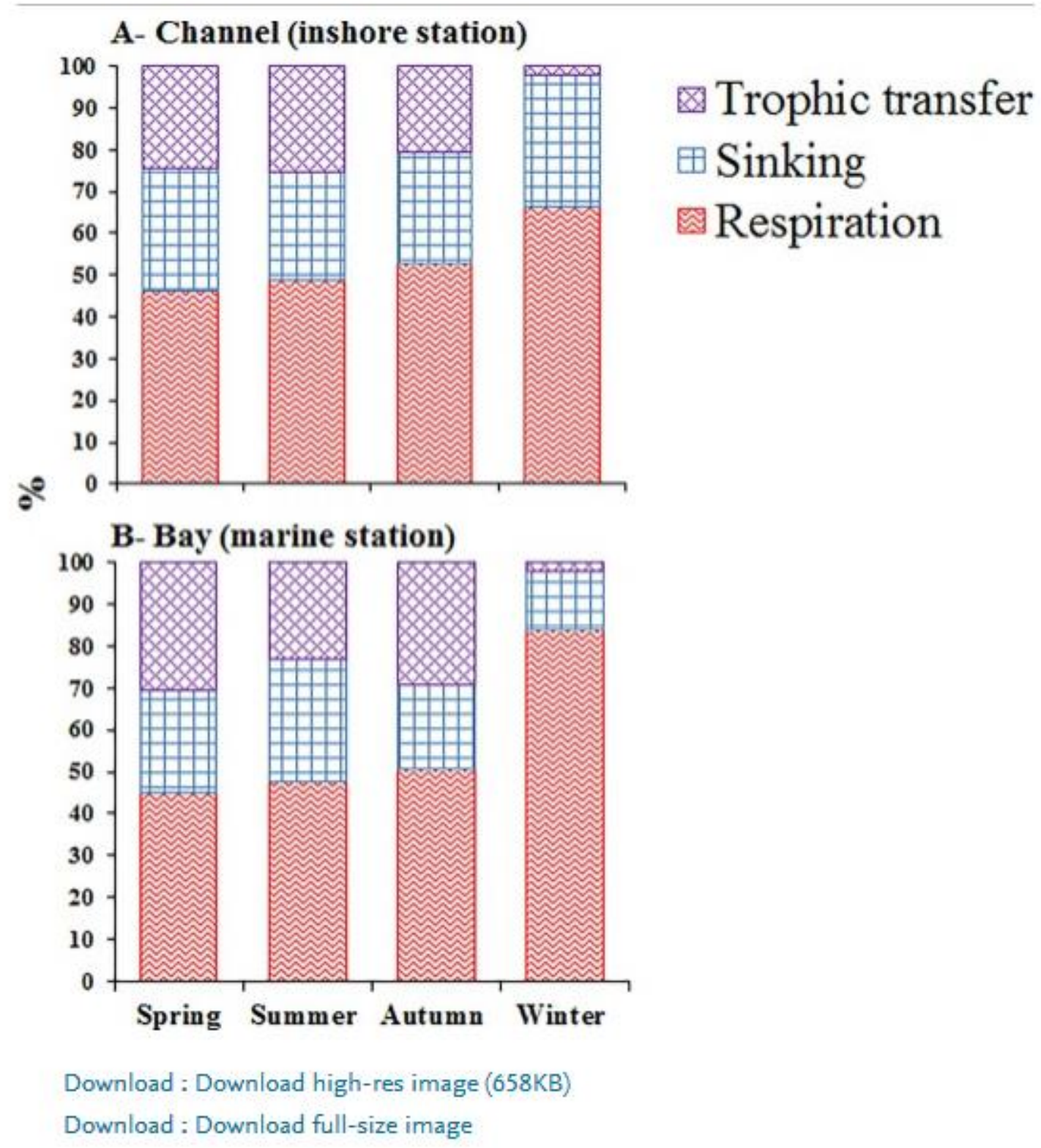

Fig. 6. Three pathways of carbon output from the planktonic food web system (as \% of gross primary production) in the inshore and marine stations over the seasons. 


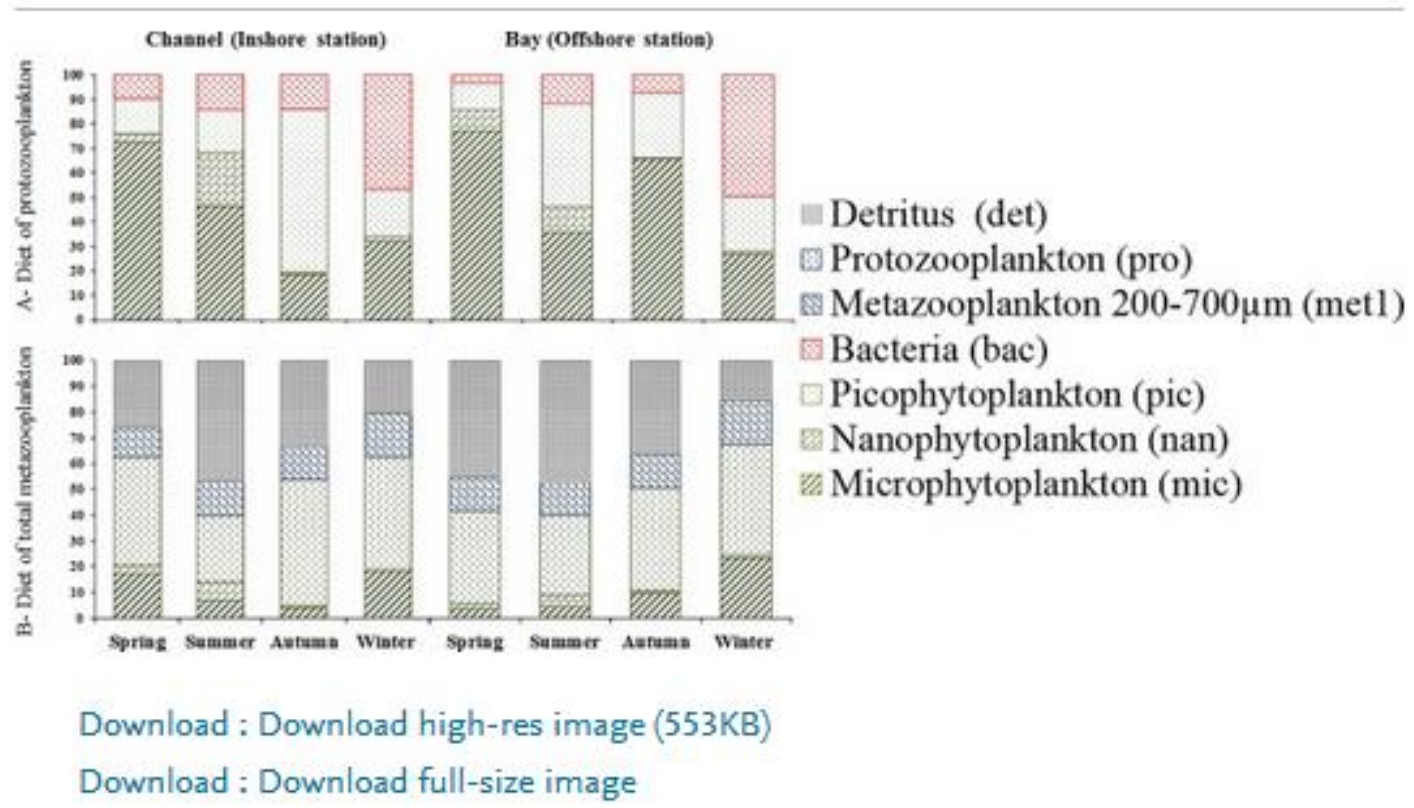

Fig. 7. Composition of diets for the protozooplankton (A) and the metazooplankton (B) in the inshore and marine stations over the seasons. 


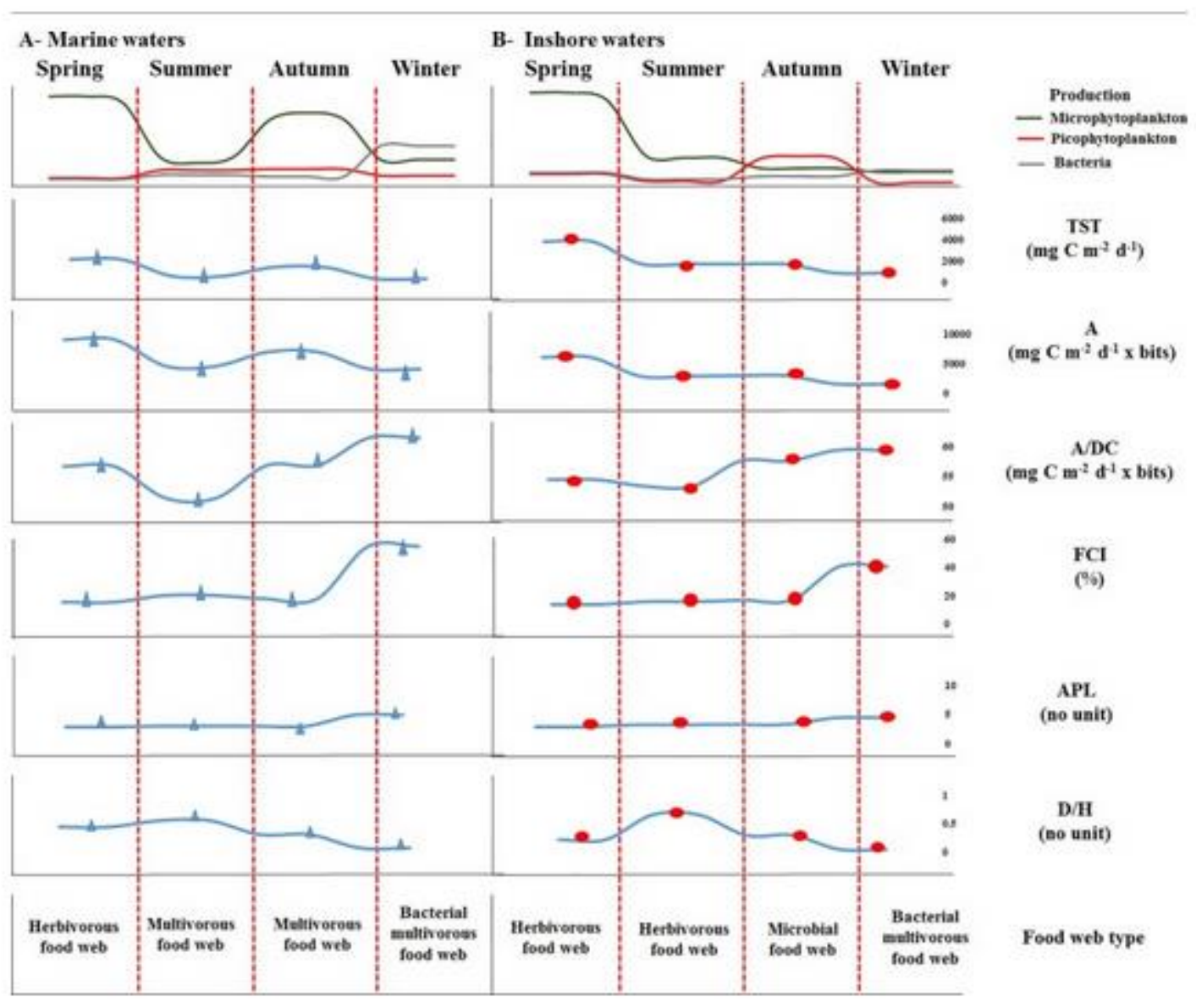

Download : Download high-res image (377KB)

Download : Download full-size image

Fig. 8. Synthetic diagram illustrating the seasonal variation of ecological indicators related to the dynamics of food web typology. 


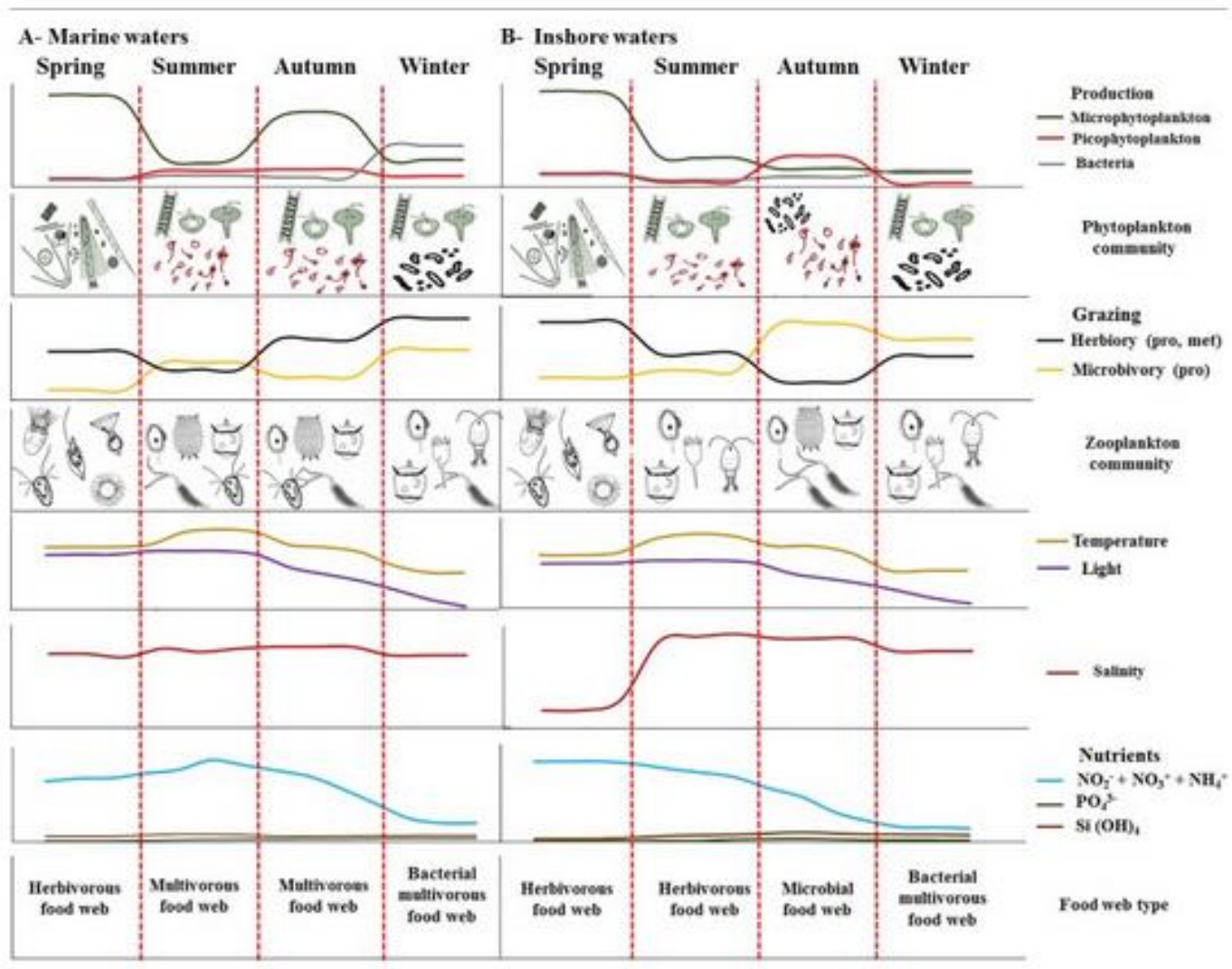

Download : Download high-res image (488KB)

Download : Download full-size image

Fig. 9. Synthetic diagram illustrating the seasonal dynamics of food web typology related to the hydrological condition and planktonic features. 


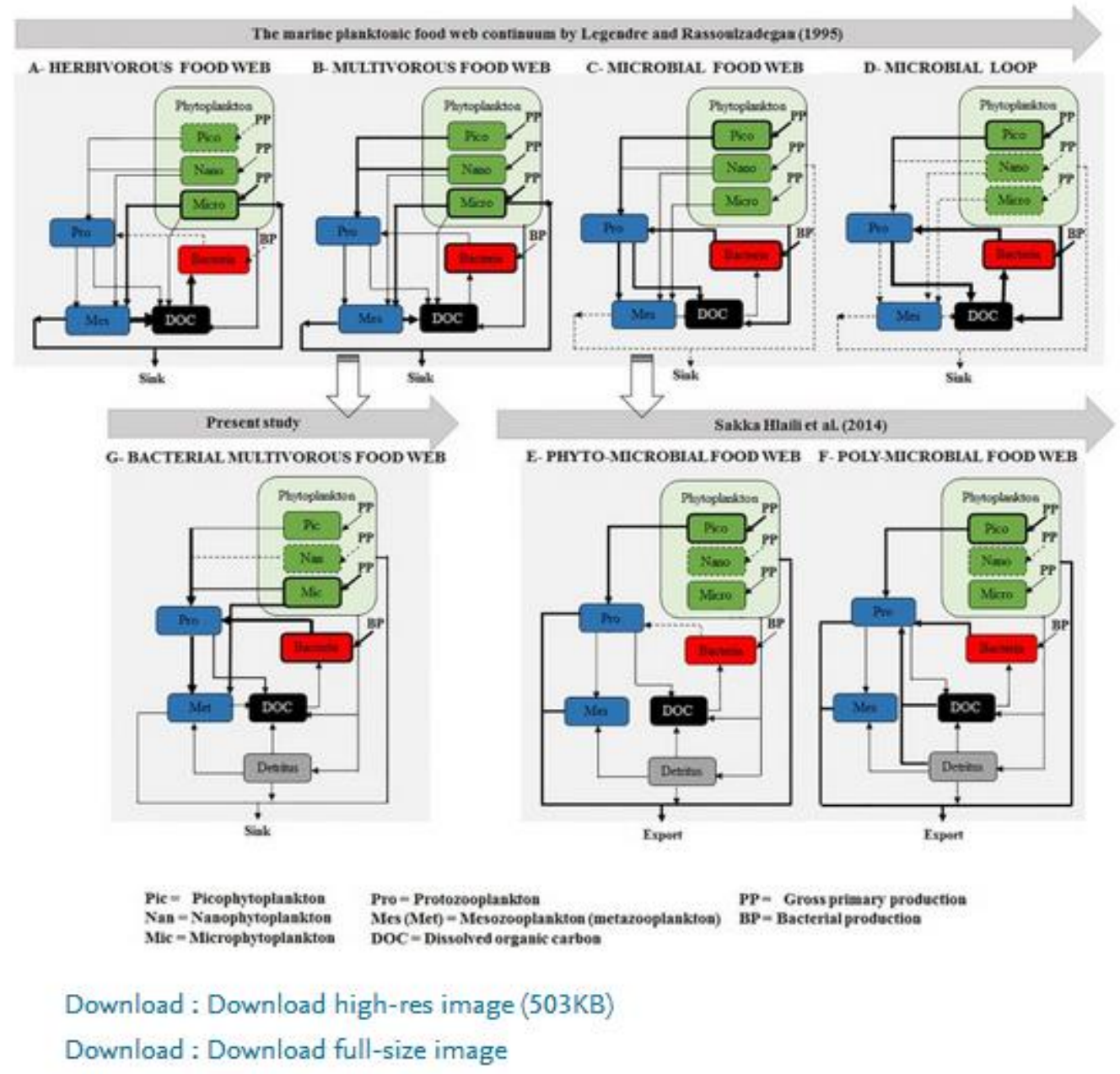

Fig. 10. Schematic representation of trophic pathways identified by Legendre and Rassoulzadegan, 1995, Sakka Hlaili et al., 2014 and in the present study. Box and arrows represent compartments with high carbon production. The thickness of arrows is proportional to the flux. 


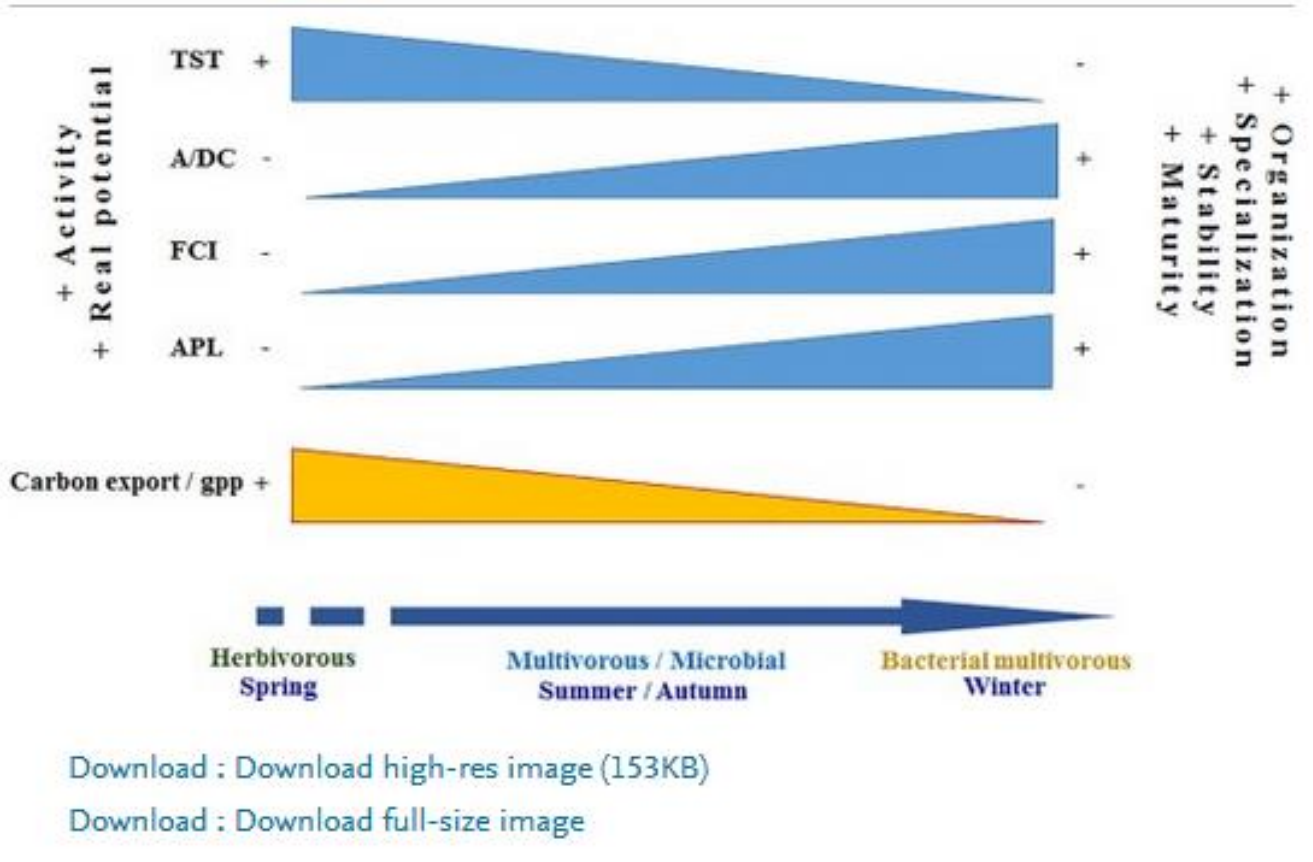

Fig. 11. Seasonal variation of trophic food webs typology in parallel with some ecological network analysis indices.

\section{Tables}

Table 1

Mass equilibrium defining linear equations used for the inverse analysis. Flow names in the LIM-MCMCwere composed of the three-letter code of the compartment of origin followed by the three-letter code of the destination compartment. Abbreviations: gpp - gross primary production, res - respiration, los - loss for the considered system.

\begin{tabular}{|c|c|c|}
\hline Compartments & Mass balance equation & Equations common to the eight models \\
\hline pic & Mass balance for picophytoplankton & gpp-pic- (pic-res + pic doc + pic pro) $=0$ \\
\hline $\operatorname{nan}$ & Mass balance for nanophytoplankton & gpp-nan $-($ nan res + nan doc + nan det + nan $p r o+$ nan-met $1+$ nan-met $2+$ nan $-l o s)=0$ \\
\hline mic & Mass balance for microphytoplankton & gpp-mic $-($ mic res + mic doc + mic det + mic pro + mic met $1+$ mic met $2+$ mic los $)=0$ \\
\hline pro & Mass balance for protorooplankton & $($ pic pro + nan pro + mic pro + bac pro $)-($ pro $r e s+$ pro doc + pro det + pro-metl + pro los $)=0$ \\
\hline \multirow[t]{2}{*}{ met1 } & Mass balance for metarooplankton & (nan-met1 + mic-met1 + pro-met1 + det met1) - \\
\hline & $200-700 \mu \mathrm{m}$ & (met1-res + met1-doc + met1-det + met1-met2 + met1-los $)=0$ \\
\hline met2 & $\begin{array}{l}\text { Mass balance for } \\
\text { metazooplankton }>700 \mu \mathrm{m}\end{array}$ & $\begin{array}{l}\text { (nan-met2 }+ \text { mic-met2 }+ \text { pro-met2 }+ \text { met1-met2 }+ \text { det met2) - } \\
(\text { met2 res }+ \text { met2-doc }+ \text { met2 det }+ \text { met2 los })=0\end{array}$ \\
\hline bac & Mass balance for bacteria & doc tac - (lac-res + bac-doc + bac pro $)=0$ \\
\hline doc & Mass balance for dissolved organic carbon & (pic-doc + nan-doc + mic-doc + pro-doc + met1-doc + met2-doc + bac-doc + det-doc) $-($ doc-bac + doc-los $)-0$ \\
\hline det & Mass balance for detritus & (nan-det + mic-det + pro-det + met1-det + met2-det) $-($ det-doe + det-met1 + det-met2 + det-los) -0 \\
\hline
\end{tabular}

pic $=$ picophytoplankton, nan $=$ nanophytoplankton, mic $=$ microphytoplankton, pro $=$ protozooplankton, metl $=$ metazooplanktonl,

met2 - metazooplankton2, bac - bacteria, doc - dissoved organic carbon, det - detritus 
Table 2

Minimum and maximum values of flows (derived from in situ measurement for each seasons) used as inequalities for the eight networks.

\begin{tabular}{|c|c|c|c|c|c|c|c|c|c|}
\hline \multirow[b]{3}{*}{ Process integrated as incqualities } & \multirow[b]{3}{*}{ Flux } & \multicolumn{2}{|l|}{ Spring } & \multicolumn{2}{|l|}{ Summer } & \multicolumn{2}{|l|}{ Autumn } & \multicolumn{2}{|l|}{ Winter } \\
\hline & & \multicolumn{8}{|c|}{ Minimum - Maximum } \\
\hline & & Channel model & Bay model & Channel model & Bay model & Channel model & Bay model & Channel model & Bay model \\
\hline pic gross primary production & gpp-pic & $54-77$ & $46-69$ & $36-53$ & $92-128$ & $202-268$ & $10-68$ & $28-38$ & $62-82$ \\
\hline nan gross primary production & gpp-nan & $88-121$ & 48-75 & 102-135 & $92-122$ & $4-6$ & $1-2$ & $4-6$ & $2-3$ \\
\hline mic gross primary production & gpp-mic & $687-904$ & $522-698$ & $208-276$ & $172-227$ & 133-175 & $326-562$ & $75-140$ & 139-206 \\
\hline pic grazing by protozooplankton & pic-pro & $17-22$ & $31-46$ & $33-36$ & $41-93$ & $168-204$ & $68-81$ & $18-28$ & $37-66$ \\
\hline nan grazing by protozooplankton & nan-pro & $73-90$ & $31-41$ & $37-51$ & $20-25$ & $2-3$ & $1-1.5$ & $2-3$ & $1.62-2.27$ \\
\hline mic grazing by protozooplankton & mic-pro & $425-468$ & $210-478$ & $80-110$ & $76-82$ & 48-65 & $190-352$ & 46-49 & $67-84$ \\
\hline doc uptake by bacteria & doe bac & 90-117 & $20-59$ & $46-61$ & $40-92$ & $42-85$ & $63-67$ & 90-135 & $244-274$ \\
\hline bacterial graxing by protorna & hac pro & $58-61$ & 13-16 & $29-32$ & 18-37 & $42-47$ & $24-53$ & $67-68$ & 137-159 \\
\hline mic sinking & miclos & $86-521$ & $29-55$ & 12-19 & $36-14$ & $31-35$ & $6-7$ & $39-57$ & $24-54$ \\
\hline nan sinking & nan los & $1.5-14$ & $1-1.5$ & $0.02-0.03$ & $0.4-0.6$ & $2-3$ & $0.3-0.5$ & $0.20-0.31$ & $0.71-0.91$ \\
\hline mic and nan graxing by met1 & mic + nan -metl & $36-49$ & 17-26 & $32-48$ & 5.8 & $9-11$ & $19-29$ & $7-8$ & $18-22$ \\
\hline mic and nan graxing by met2 & mic + nan-met2 & $66-85$ & $0.12-0.16$ & $0.10-0.20$ & $14-21$ & $0.05-0.08$ & 7-19 & $14-18$ & $40-52$ \\
\hline met1 + met2 sinking & met1 + met2 los & $16^{*}$ & $21^{*}$ & $0.65^{\circ}$ & $0.62^{2}$ & $4.24^{2}$ & $0.91^{*}$ & $0.47^{\star}$ & $0.48^{*}$ \\
\hline det sinking & det los & $2361^{42}$ & $657^{* 4}$ & $6849^{4 *}$ & $1611^{\star *}$ & $4126^{4 t}$ & $7083^{4 .}$ & 1238.4 & $684^{2 .}$ \\
\hline
\end{tabular}

All flows are considered as intervals between the minimum and maximum values estimated in situ, with the following exceptions:

* Flows considered as minimum

* Flows considered as maximum

Table 3

Flows description and values ( $\mathrm{mg} \mathrm{C} \mathrm{m}^{-2} \mathrm{~d}^{-1}$ ) estimated by the LMM-MCMC for the eight planlton food webr.

\begin{tabular}{|c|c|c|c|c|c|c|c|c|c|}
\hline \multirow{3}{*}{ Descriptod } & \multirow{3}{*}{ Symbie } & \multicolumn{8}{|c|}{ lateriad wale $\left(\mathrm{mg} \mathrm{C} \mathrm{m}^{-2} \mathrm{~d}^{-1}\right)$} \\
\hline & & \multicolumn{2}{|l|}{ Spring } & \multicolumn{2}{|l|}{ Semmer } & \multicolumn{2}{|l|}{ Netwa } & \multicolumn{2}{|l|}{ Wate } \\
\hline & & $\begin{array}{l}\text { Ounnd } \\
\text { model }\end{array}$ & Ray modd & $\begin{array}{l}\text { Clunind } \\
\text { model }\end{array}$ & Ray malel & $\begin{array}{l}\text { Owninel } \\
\text { model }\end{array}$ & Ray moded & $\begin{array}{l}\text { Oannid } \\
\text { modil }\end{array}$ & Ray modd \\
\hline 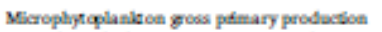 & gpmense & 795 & 600 & 242 & 199 & 154 & 453 & 123 & 180 \\
\hline 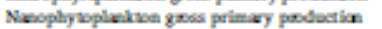 & gp-an & 65 & 61 & 118 & 107 & 5 & 2 & 5 & 3 \\
\hline 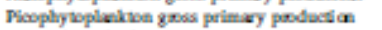 & gepple & 106 & 56 & 44 & 100 & 236 & 117 & 33 & 73 \\
\hline 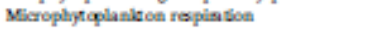 & mberes & 40 & 32 & 12 & 10 & 8 & 35 & 6 & 9 \\
\hline 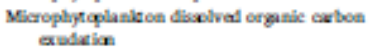 & mbedoe & 69 & 54 & 21 & 17 & 13 & 49 & 11 & 16 \\
\hline Merophytoplanis on der podbetín & miscer & 35 & 143 & 77 & 41 & 34 & 76 & 0.2 & 0.3 \\
\hline 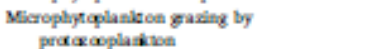 & mbepro & 444 & $3 x$ & 95 & 79 & 56 & 250 & 46 & 74 \\
\hline 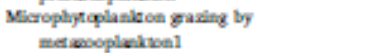 & mbemed 1 & 33 & 15 & 20 & 3 & 10 & 24 & 6 & 18 \\
\hline 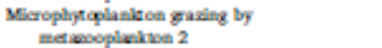 & mbemex 2 & 66 & o. & 006 & 9 & 004 & 13 & 13 & 40 \\
\hline Meroplynoplanklson sinkeg & mbetos & 100 & 40 & 15 & 40 & 33 & 6 & 40 & 24 \\
\hline Neoplyboplekhon respinein & meses & 4 & 4 & 6 & 6 & 0.3 & 0.1 & 0.2 & a.1 \\
\hline 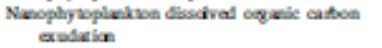 & nowdoe & 6 & 6 & 10 & 9 & 05 & 0.2 & 0.4 & 0.3 \\
\hline 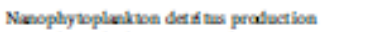 & maset & 9 & 7 & 37 & 57 & a. & 0.02 & 0.2 & a. \\
\hline 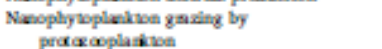 & nowpro & 19 & 36 & 44 & 23 & 2 & 1 & 3 & 2 \\
\hline 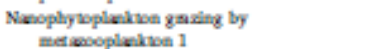 & nesmet & 9 & 7 & 20 & 3 & a. & 0.02 & 1 & $\infty \omega_{1}$ \\
\hline 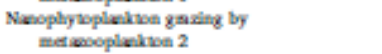 & men-med & 9 & o.1 & 0.06 & 9 & 0.03 & 0.03 & 1 & $\infty \infty 1$ \\
\hline Neoply woplekhow sinking & nowlos & 9 & 1 & 0.03 & 0.5 & 2 & 0.4 & 0.2 & 1 \\
\hline 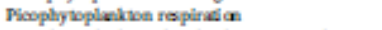 & puevers & 6 & 4 & 3 & 7 & 12 & 6 & 2 & 4 \\
\hline 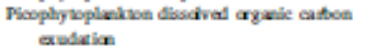 & pledoer & 9 & 6 & 4 & 10 & 20 & 10 & 3 & 6 \\
\hline 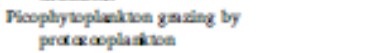 & plespro & $\infty$ & 46 & 36 & 92 & 208 & 101 & 28 & 62 \\
\hline Pracomplanisan nespiabon & poores & 181 & $1 Z \bar{Z}$ & 63 & 67 & 80 & 113 & 39 & 89 \\
\hline  & pos boe & 95 & 66 & 33 & 35 & 47 & 59 & 38 & 89 \\
\hline Pracomplanilea detitus prodoeson & pos-det & 94 & 64 & 31 & 33 & 46 & 58 & 20 & 28 \\
\hline 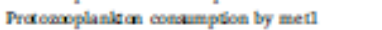 & posmen & 158 & $m$ & 43 & 50 & 76 & 91 & 42 & 69 \\
\hline 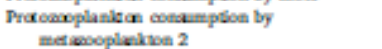 & posmet? & 84 & 66 & 35 & 34 & 46 & 58 & 5 & a. \\
\hline Mermopivinot 1 repirabon & mel-ses & 92 & 80 & 54 & 45 & 43 & 63 & 19 & 36 \\
\hline 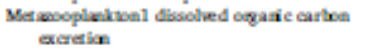 & menldoe & 47 & 41 & 28 & 23 & 22 & 33 & 18 & 36 \\
\hline 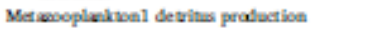 & men-det & 45 & 30 & 26 & 22 & 21 & 31 & 10 & 11 \\
\hline  & mell-met & 67 & 60 & 42 & 33 & 33 & 48 & 19 & 28 \\
\hline Merrosopleikionl sinking & ment-bea & 38 & 31 & 21 & 18 & 16 & 25 & 1 & 002 \\
\hline 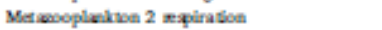 & meo-res & 96 & 68 & 45 & 43 & 37 & 57 & 13 & 22 \\
\hline 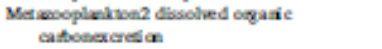 & mee-soe & 48 & 35 & 23 & 22 & 19 & 29 & 12 & 22 \\
\hline  & mes-det & 46 & 32 & 21 & 21 & 18 & 27 & 6 & 7 \\
\hline Meriosopheinot 2 anking & meedeses & 96 & 69 & 45 & 44 & 38 & 58 & 11 & 17 \\
\hline Racesa respinebion & baces & 26 & 13 & 14 & 20 & 19 & 16 & 27 & 55 \\
\hline 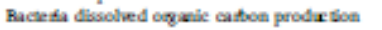 & bac-de & 32 & 21 & 17 & 90 & 23 & 22 & 40 & 82 \\
\hline Raeseda growing by procomplanisas & bas.po & 58 & 14 & 29 & 26 & 42 & 28 & 67 & 13 \\
\hline 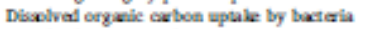 & dxther & 117 & 48 & 60 & $\pi$ & 85 & 65 & 135 & 274 \\
\hline 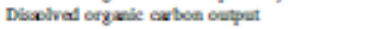 & dxtas & 236 & 228 & 103 & 96 & 81 & 167 & 0.5 & $\infty 01$ \\
\hline Deratm diwolubon & deste & 46 & 43 & 26 & 25 & 21 & 31 & 13 & 22 \\
\hline Derates condempton by metreoplakital & desment & 89 & 190 & 87 & 84 & 50 & 85 & 17 & 24 \\
\hline 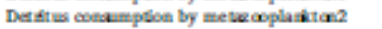 & desente & 61 & 78 & 56 & 44 & 53 & 33 & 5 & a.1 \\
\hline Derat $=$ aking & desta & 34 & 34 & 23 & 20 & 16 & 25 & 1 & 0.1 \\
\hline
\end{tabular}


Table 4

\begin{tabular}{|c|c|c|c|c|c|}
\hline Proces & Coecriad eceparment & Boend & Dectipses & Equscos & Referese \\
\hline \multirow[t]{3}{*}{ Respiatos } & 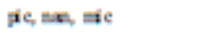 & $\begin{array}{l}\text { Loner } \\
\text { Upper }\end{array}$ & 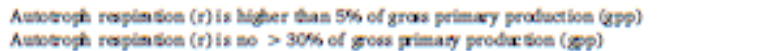 & $\begin{array}{l}5 \% 8 p<<F \\
;<30 \% g r p\end{array}$ & Vexima asd Vas (1988) \\
\hline & ine & Lomer & 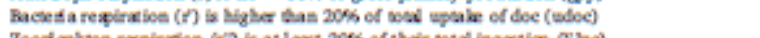 & $200 \%$ nobee $<\%$ & Verima asd Sarakoff (19m) \\
\hline & $\mathrm{Fr}_{0}, \mathrm{me} 1, \mathrm{~m}, \mathrm{e}$ & Lomer & 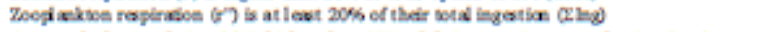 & $20 \%$ Ing $<r^{\circ}$ & Veima asd Sarekedf (1969) \\
\hline \multirow[t]{4}{*}{ 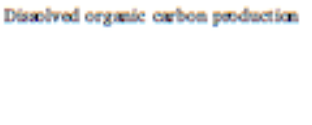 } & $\mathrm{Fe},=\mathrm{n}, \mathrm{ae}$ & $\begin{array}{l}\text { Lomer } \\
\text { Upper }\end{array}$ & 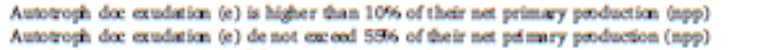 & $\begin{array}{l}10 \% \operatorname{spp}<e \\
e<55 \% \operatorname{mpp}\end{array}$ & Vesian asd sareked (19m) \\
\hline & $\mathrm{Fo},=\mathrm{m} 1, \mathrm{~m}=0$ & Lomer & 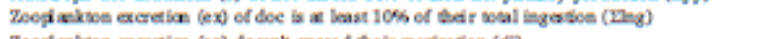 & $10 \% \mathrm{n}=\mathrm{m}<\alpha$ & Vexiana asd Pace (9994) \\
\hline & & Upper & 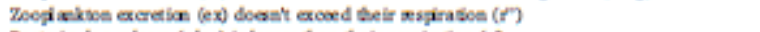 & $e x<r^{n}$ & Veina and Vas (9968) \\
\hline & Ine & Upper &  & redoe $<z^{\prime}$ & Verian asd Pace (1994) \\
\hline \multirow[t]{3}{*}{ Gow ÂA effieincy } & $\mathbf{m o},=e 1,=\infty$ & Lomer & 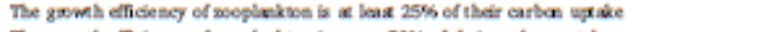 & $25 \% \mathrm{Ih} g<\mathrm{hg} \cdot \theta^{\prime \prime}+\alpha+\operatorname{det} 0$ & Vesimas asd Palow (2003) \\
\hline & & Upper & 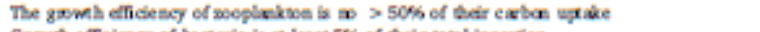 & 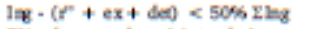 & Vezina asd Pallow (2003) \\
\hline & the & Lener & 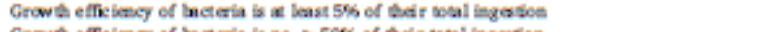 & $5 \%$ whe $<$ wiee $-\left(r^{\prime}+\right.$ nde $)$ & Vesisasd Palow (2003) \\
\hline \multirow{2}{*}{ Aximbiabon effisency } & & Upper & 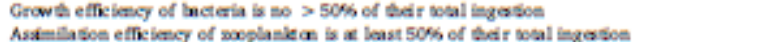 & 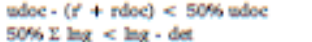 & 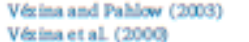 \\
\hline & 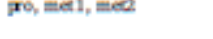 & Unect &  & $50 \% \mathrm{mg}<\mathrm{mg} \cdot \mathrm{det}$ & \\
\hline \multirow{2}{*}{ Desines produstos } & $\mathbf{p r},=\mathrm{el}, \mathrm{m}=\infty$ & Lewer & 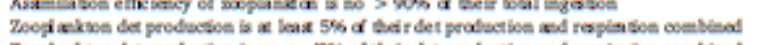 & 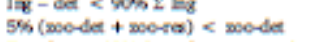 & Steinterg o a a (0000) \\
\hline & & Upper & 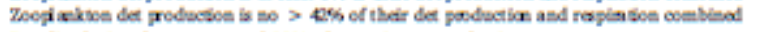 & Zooder $<42 \%$ (modst + meres $)$ & \\
\hline Desines disobutos & de & $u_{\text {ppe }}$ & 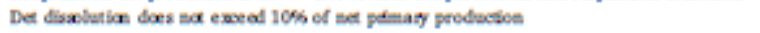 & deldoe $<10 \%=p$ & Pace of al (a984) \\
\hline
\end{tabular}


Table 5

Fcological indicators used for the Channel and the Bay models. Nomenclature of symbols used in formula calculation of network index equations: i: flow out of the system from $i, i=1, \ldots n ; j$; flow into the system to $j, j=1 \ldots n ; T_{i}$ : Total outflow from compartment $i ; T_{j}:$ Total inflow for compartment $j$; and Tij: Flow from compartment $i$ to compartment $j$. TSTe is the total flow that is recycled, $\mathrm{Z}$ equals the sum of all exogenous inputs.

\begin{tabular}{|c|c|c|c|c|}
\hline Ecological indicator & Definition & Formula calculation & Unit & Reference \\
\hline $\begin{array}{l}\text { Total System Throughput } \\
\text { (ISI) }\end{array}$ & $\begin{array}{l}\text { The sum of all the flows circulating through all compartments } \\
\text { and a measure of the total system activity. }\end{array}$ & $\mathrm{TST}=\sum_{\mathrm{l}-1, \mathrm{~J}-1}^{\mathrm{n}} \mathrm{Tt}_{\mathrm{t}}$ & $\mathrm{mg} \mathrm{C} \mathrm{m}^{-2} \mathrm{~d}^{-1}$ & Kay et al. (1989) \\
\hline Ascendency $(A)$ & $\begin{array}{l}\text { Ascendency represents the organized part of the ceosystem and } \\
\text { merges the quantification of the system activity and the degrec of } \\
\text { specialization. }\end{array}$ & $A=\Sigma_{\mathbf{g}}\left(T_{\mathrm{II}}\right) * \log \left(\frac{T_{\mathrm{I}} * 1 \mathrm{ST}}{T_{\mathrm{J}} * T_{\mathrm{I}}}\right)$ & $\begin{array}{l}\mathrm{mg} \mathrm{C} \mathrm{m} \mathrm{m}^{-2} \\
\mathrm{~d}^{-1} \times \text { bits }\end{array}$ & $\begin{array}{l}\text { Ulanowicz and Wulff } \\
\text { (1991) and Ulanowicz } \\
\text { (2000) }\end{array}$ \\
\hline $\begin{array}{l}\text { Development Capacity } \\
\text { (DC) }\end{array}$ & $\begin{array}{l}\text { Represents the maximum possible value of Ascendency that an } \\
\text { ecosystem may reach. }\end{array}$ & $\mathrm{DC}=-\mathrm{TST} \cdot \Sigma_{\mathrm{I}} \frac{\mathrm{T}_{\mathrm{II}}}{\mathrm{TST}} \cdot \log \left(\frac{\mathrm{T}_{\mathrm{I}}}{\mathrm{TST}}\right)$ & $\begin{array}{l}\mathrm{mg} \mathrm{C} \mathrm{m} \mathrm{m}^{-2} \\
\mathrm{~d}^{-1} \times \text { bits }\end{array}$ & $\begin{array}{l}\text { Ulanowicz and Wulff } \\
\text { (1991) and Ulanowicz } \\
\text { (2000) }\end{array}$ \\
\hline $\begin{array}{l}\text { Relative Ascendency (A/ } \\
\text { DC) }\end{array}$ & $\begin{array}{l}\text { Defines the ecosystem degree of development. High NDC ratios } \\
\text { reflect a high degree of organization, highly specialized and less } \\
\text { redundant pathways. }\end{array}$ & $\hat{\Lambda} \overline{\mathrm{DC}}$ & $\%$ & Baird et al. (1991, 1998] \\
\hline $\begin{array}{l}\text { Average Path Length } \\
\text { (APL.) }\end{array}$ & $\begin{array}{l}\text { It is the average number of compartments crossed by a unit of } \\
\text { carbon from entering to exiting the ecosystem, Represents a } \\
\text { measure of the ecosystem retention capacity. }\end{array}$ & APL. $=\frac{T S T-\Sigma_{1} \text { umports }}{\Sigma_{1} \text { umports }}$ & no unit & $\begin{array}{l}\text { Kay et al. (1989) and } \\
\text { Baird et al. (1991) }\end{array}$ \\
\hline Finn Cycling Index (FCI) & $\begin{array}{l}\text { Quantifies the fraction of all flows involved in recycling and can } \\
\text { be considered as a measure of the retentiveness of the system. }\end{array}$ & $\mathrm{FCl}=\frac{\mathrm{TSTC}}{\mathrm{TST}}$ & $\%$ & Finn (1976) \\
\hline $\begin{array}{l}\text { Detritivory/Herbivory } \\
\text { (D/H) }\end{array}$ & $\begin{array}{l}\text { Indicates the importance of living trophic interactions compared } \\
\text { to detritus chain. }\end{array}$ & $\frac{\mathrm{D}}{\mathrm{n}}$ & No unit & Ulanowicz (1992) \\
\hline
\end{tabular}

Table 6

Results of the Cliffs'8 test applied to ecological network indices calculated for the Channel and the Bay over the four seasons. Comparison was made between seasons (spring/summer, spring/autumn, spring/winter, summer/autumn, summer/winter and winter/autumn) for each ecological indices (TST, A, DC, A/DC, APL, FCI and D/H. Asterisk Between brackets represent the magnitude of the effect (***): large and (ns) negligible effects.

\begin{tabular}{|c|c|c|c|c|c|c|c|}
\hline & & Spring/Summer & Spring/Autumn & Spring/Winter & Summer/Autumn & Summer/Winter & Winter/Autumn \\
\hline \multirow[t]{7}{*}{ Channel (inshore station) } & TST & $0.99(\ldots)$ & $0.99(\ldots)$ & $0.99(\ldots)$ & $0.99(\ldots)$ & $0.99(\ldots)$ & $0.99(\ldots)$ \\
\hline & A & $0.99(\ldots)$ & $0.99(\ldots)$ & $0.99(\ldots)$ & $0.99(\ldots)$ & $0.99(\ldots)$ & $0.99(\ldots)$ \\
\hline & DC & $0.99(\ldots)$ & $0.99(\ldots)$ & $0.99(\ldots)$ & $0.99(\ldots)$ & $0.99(\ldots)$ & $0.99(\ldots)$ \\
\hline & $\mathrm{A} / \mathrm{DC}$ & $0.54(\ldots)$ & $0.54(\ldots)$ & $-0.99(\ldots)$ & $0.54(\ldots)$ & $-0.99(\ldots)$ & $0.99(\ldots)$ \\
\hline & APL. & $-0.92(\ldots)$ & $0.99(\ldots)$ & $-1(\ldots)$ & $0.99(\ldots)$ & $-1(\ldots)$ & $0.99(\ldots)$ \\
\hline & $\mathrm{FCI}$ & $-0.67(\ldots)$ & $0.99(\ldots)$ & $-1(\ldots)$ & $0.99(\ldots)$ & $-1(\ldots)$ & $0.99(\ldots)$ \\
\hline & $\mathrm{D} / \mathrm{H}$ & $0.99(\ldots)$ & $0.99(\ldots)$ & $0.99(\ldots)$ & $0.99(\ldots)$ & $0.99(\ldots)$ & $0.99(\ldots)$ \\
\hline \multirow[t]{7}{*}{ Bay (marine station) } & TST & $0.99(\ldots)$ & $0.99(\ldots)$ & $0.99(\ldots)$ & $-0.99(\ldots)$ & $0.99(\ldots)$ & $0.99(\ldots)$. \\
\hline & A & $0.99(\ldots)$ & $0.99(\ldots)$ & $0.99(\ldots)$ & $-0.99(\ldots)$ & $0.87(\ldots)$ & $0.99(\ldots)$ \\
\hline & DC & $0.99(\ldots)$ & $0.99(\ldots)$ & $0.99(\ldots)$ & $-0.99(\ldots)$ & $0.99(\ldots+)$ & $0.99(\ldots)$. \\
\hline & A/DC & $0.95(\ldots)$ & $-0.01(\mathrm{~ns})$ & $-0.94(\ldots)$ & $-0.96(\ldots)$ & $-1(\ldots)$ & $-0.96(\ldots)$ \\
\hline & API. & $-0.62(\ldots .)$. & $-0.53(\ldots)$ & $-1(\ldots)$ & $0.12(\mathrm{~ns})$ & $-1(\ldots)$ & $-1(\ldots)$ \\
\hline & FCI & $-0.94(\ldots)$ & $-0.60(\ldots)$ & $-1(\ldots)$ & $0.87(\ldots)$ & $-1(\ldots)$ & $-1(\ldots)$ \\
\hline & $\mathrm{D} / \mathrm{H}$ & $0.99(\ldots)$. & $0.99(\ldots)$ & $0.99(\ldots)$ & $0.99(\ldots)$ & $0.99(\ldots)$ & $0.99(\ldots)$. \\
\hline
\end{tabular}

